\title{
OPEN The Hopewell airburst event, 1699-1567 years ago (252-383 CE)
}

\author{
Kenneth Barnett Tankersley ${ }^{1,2,5 \bowtie}$, Stephen D. Meyers ${ }^{2,5}$, Stephanie A. Meyers ${ }^{3,5}$, \\ James A. Jordan ${ }^{4,5}$, Louis Herzner ${ }^{1,5}$, David L. Lentz ${ }^{3,5}$ \& Dylan Zedaker ${ }^{1,5}$
}

Meteorites, Fe and Si-rich microspherules, positive Ir and Pt anomalies, and burned charcoal-rich Hopewell habitation surfaces demonstrate that a cosmic airburst event occurred over the Ohio River valley during the late Holocene. A comet-shaped earthwork was constructed near the airburst epicenter. Twenty-nine radiocarbon ages establish that the event occurred between 252 and $383 \mathrm{CE}$, a time when 69 near-Earth comets were documented. While Hopewell people survived the catastrophic event, it likely contributed to their cultural decline. The Hopewell airburst event expands our understanding of the frequency and impact of cataclysmic cosmic events on complex human societies.

Direct positive evidence of catastrophic cosmic airburst and impact events have been found in the Western Hemisphere at the Cretaceous and Tertiary (KT) boundary 65 million years ago and at the Younger Dryas (YD) boundary $\sim 12,800$ years ago ${ }^{1,2}$. Both of these events are associated with global mass extinctions and they occurred before humans culturally evolved into complex, sedentary, agricultural-based societies. The recent discovery of two Holocene cosmic impact events in Argentina ( 6000 B.P. and 3000 B.P.), and one in Jordan $(\sim 3,700$ B.P.), suggests that these natural catastrophes are far more common than previously suspected ${ }^{3,4}$. Between 1,800 and 1431 years ago $(220$ and $589 \mathrm{CE})$, Chinese astronomers documented 69 near-Earth comets $(<1.3$ au and a period of revolution $<200$ years), including Haley's, which came within 0.09 au of earth in 374 CE (1646 B.P. $)^{5}$. At this time, human communities and the resources they needed for survival were at a heightened risk of being destroyed by a comet airburst event.

Comets are dirty fractured snowballs composed of cosmic dust, frozen gases, and meteoroids ${ }^{6}$. In some cases, comets such as SL9 break apart and impact planets ${ }^{7}$. If a comet fragment fell into the high-pressure air of earth's thermosphere, an explosion, known as an airburst, would release a devastating high-energy shockwave over a large area resulting in burned agricultural fields, buildings, and forests as evidenced by the Tunguska event of $1908^{8}$. Comet airburst events produce meteorites, iron $(\mathrm{Fe})$ and silicon $(\mathrm{Si})$ rich microspherules, and positive anomalies of iridium $(\mathrm{Ir})$ and platinum $(\mathrm{Pt})^{9}$.

Archaeological evidence of ancient cosmic impact events has been recovered from archaeological sites of various ages in Europe, the Near East, and China ${ }^{10,11}$. In the western Hemisphere, Hopewell archaeological sites in the Ohio River valley contain an anomalously high concentration and diversity of meteorites when compared to all other cultural periods. They include iron meteorites (e.g., ataxites, hexahedrites, octahedrites), stony iron meteorites (e.g., mesosiderites, pallasites), and stony meteorites (e.g., olivine hypersthene chondrites) ${ }^{12}$.

The spatial distribution, contexts, and diverse composition of Hopewell meteorites has been explained as acquisition through long-distance exchange systems and trade networks ${ }^{13-17}$. It is possible, however, that many of the Hopewell meteorites resulted from a single cosmic airburst event. Comets contain a variety of meteoroids with different elemental and mineralogical composition. Here, we present the results of an interdisciplinary examination of multi-proxy evidence for a Hopewell comet airburst event from the systematic investigations of eleven archaeological sites in the Ohio River valley. We use radiocarbon and typological dating to determine the timing of the event and we suggest that it may have contributed to the social decline of the Hopewell.

Hopewell. Genetic analyses demonstrate that modern Native Americans are the direct descendants of the Hopewell ${ }^{18,19}$. The archaeological hallmarks of the Hopewell include monumental landscape architecture-the largest geometric earthen enclosures in the world, intricate water management systems, massive burial mounds, and extensive ceremonial centers ${ }^{20,21}$. Distinctive symbols, artwork, and exotic goods, which have been traced

\footnotetext{
${ }^{1}$ Department of Anthropology, Department of Geology, University of Cincinnati, Cincinnati, OH 45221, USA. ${ }^{2}$ Department of Geology, University of Cincinnati, Cincinnati, OH 45221, USA. ${ }^{3}$ Department of Biology, University of Cincinnati, Cincinnati, OH 45221, USA. ${ }^{4}$ Reston Stable Isotope Laboratory, United States Geological Survey, Reston, VA 20192, USA. ${ }^{5}$ These authors contributed equally: Kenneth Barnett Tankersley, Stephen D. Meyers, Stephanie A. Meyers, James A. Jordan, Lovis Herzner, David L. Lentz and Dylan Zedaker. ${ }^{\circledR}$ email: tankerkh@uc.edu
} 


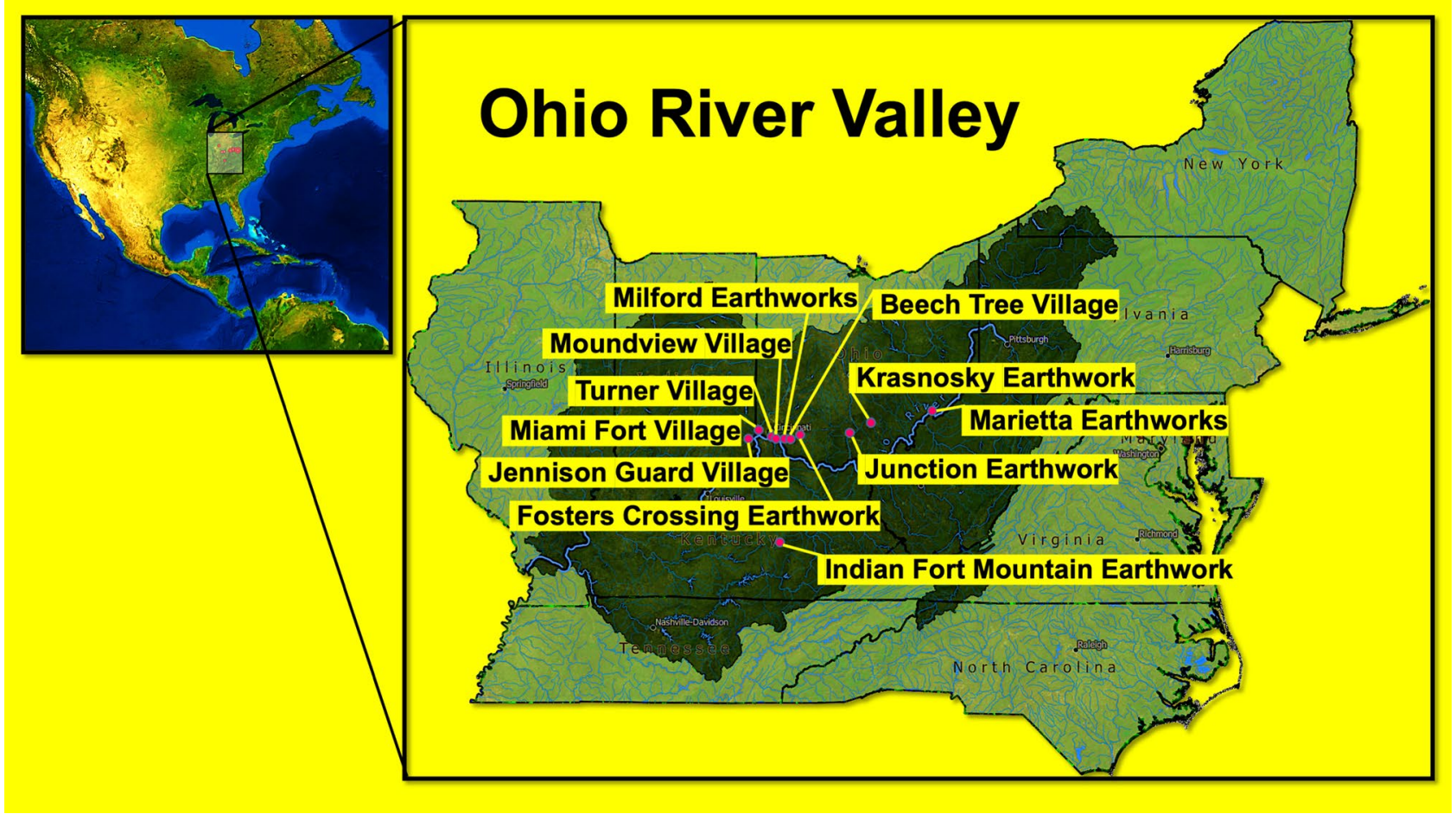

Figure 1. Geographic setting of Hopewell archaeological study sites for airburst-related proxies: JennisonGuard village site, Indiana; Miami Fort hilltop earthworks, Ohio; Turner earthworks and village, Ohio; Moundview village and mound, Ohio; Milford earthworks, Ohio; Beech Tree village, Ohio; Foster's Crossing earthwork, Ohio; Krasnosky earthworks, Ohio; Indian Fort Mountain earthworks, Kentucky; Junction earthworks, Ohio; and Marietta earthworks and mounds, Ohio. Kenneth Barnett Tankersley used Microsoft PowerPoint for Mac Version 16.41 (www.microsoft.com) to create this figure.

from unprecedented continental distances of more than $2400 \mathrm{~km}$ indicate that the Hopewell had a widespread social network between $100 \mathrm{BCE}$ and $400 \mathrm{CE}$, which spanned the Atlantic Ocean to the Rocky Mountains and from Canada to the Gulf of Mexico ${ }^{22}$. The spatial and temporal distribution of Hopewell archaeological sites are associated with a stable and sedentary society with a political hierarchy. The greatest concentration of Hopewell archaeological sites occurs in the Ohio River valley with the largest ceremonial centers (hundreds of hectares) located along the tributaries of the Scioto and the Little and Great Miami rivers ${ }^{23,24}$.

The earliest investigations of Hopewell archaeological sites began in the eighteenth century and accelerated during the late nineteenth and twentieth century, resulting in detailed site maps, chronometric ages, and artifact provenances ${ }^{23,24}$. While past investigations have focused on Hopewell economies, mortuary practices, sociopolitical interaction, social stratification, and symbolism, the reason for the rapid cultural decline of the Hopewell $\sim$ 1,600 B.P. remains unresolved ${ }^{25}$. Theoretically, a comet airburst event is a possible explanation for the cultural downturn given that the period of near-Earth comets occurred immediately prior to the terminal age of Hopewell archaeological sites. In order to address this possibility, we examined the contextual and temporal evidence of comet airburst-related proxies at eleven Hopewell sites in the Ohio River valley (Fig. 1).

\section{Results}

Comet airburst-related proxies. Our interdisciplinary research focused on five comet airburst-related proxies including meteorites, Fe and Si-rich microspherules, positive Ir and Pt anomalies, and burned carbonrich habitation surfaces on Hopewell archaeological sites in the Ohio River valley. Hopewell habitation surfaces were selected that exhibit no or minimal signs of bioturbation or other natural or cultural disturbance (Figs. 2, $3,4,5,6,7,8,9,10,11,12$ ). Midden deposits and other anthropogenic features were not sampled (Section S1). Of the eleven archaeological sites, which we investigated, meteorites were found at the Turner earthworks and village in Hamilton County, Ohio and the Marietta earthworks and mounds in Washington County, Ohio. The Marietta meteorite was collected in $1819^{13,16,26}$. Since $1882,>1,600 \mathrm{~g}$ of pallasites have been excavated from the Turner site (Fig. 13) ${ }^{27-29}$. Some of the meteorites recovered historically were burned and hammered into thinly pounded sheets used in the production of jewelry and musical instruments and interred with human remains $s^{30}$.

It long has been assumed that meteorites from the Turner site were pieces of the Brenham pallasite obtained from Kiowa County, Kansas through trade ${ }^{13,14}$. However, the concentrations of Ga and Ge in the Turner specimens are $10 \%$ lower than the Brenham pallasite ${ }^{12}$. While the Ir concentration of the Turner meteorites is well within the range found in the Brenham pallasite the level of $\mathrm{Pt}$ is five times lower (Section S1). In order to determine if the pallasite meteorites from the Turner site resulted from a cosmic impact event, sediment from the village habitation stratum was petrographically examined for meteorites. 


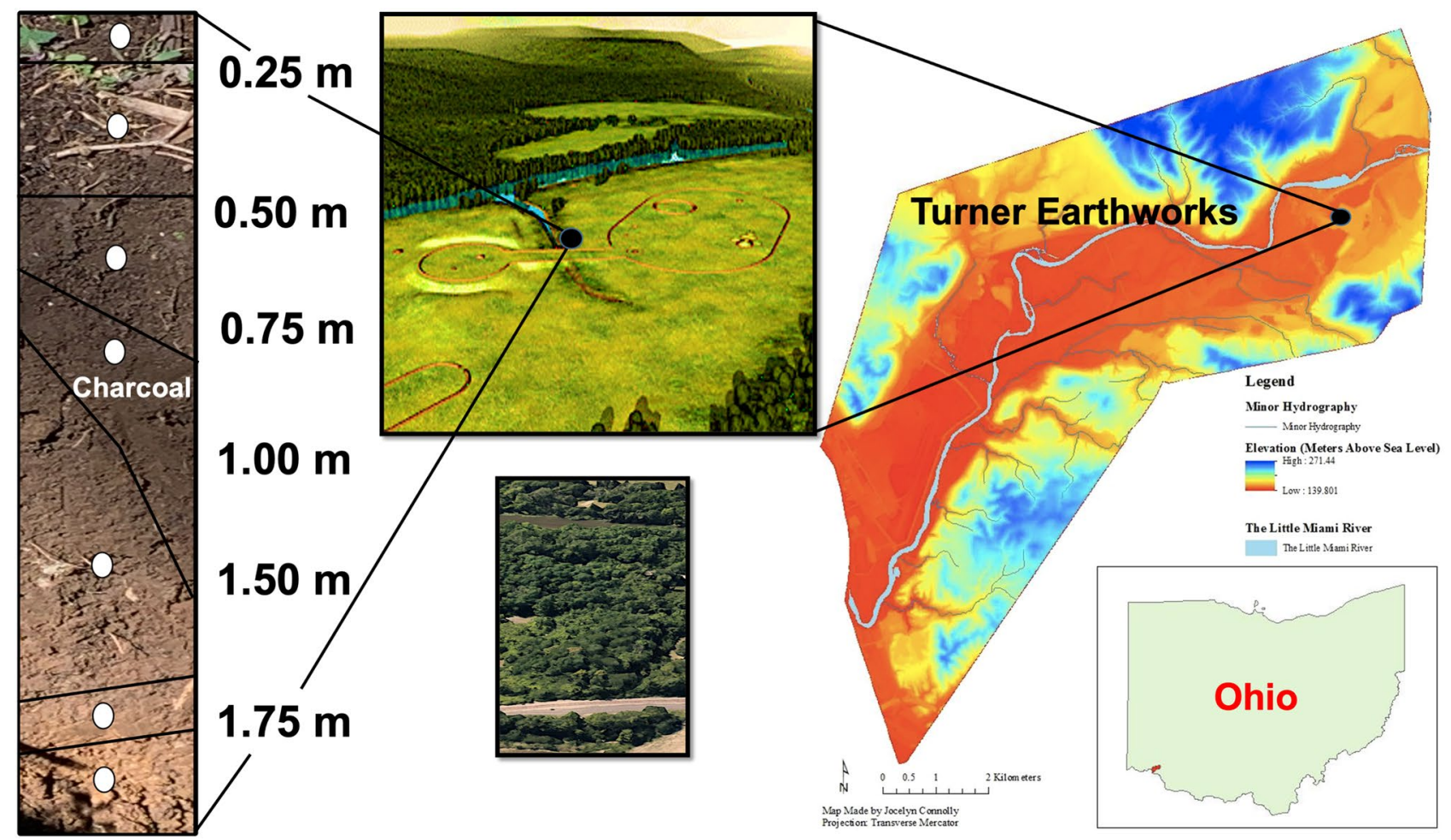

Figure 2. The location, stratigraphy, and sediment sample sites (white circles) of the Turner earthworks and village site, Hamilton County, Ohio. Kenneth Barnett Tankersley used Microsoft PowerPoint for Mac Version 16.41 (www.microsoft.com) to create this figure. The GIS map was produced in ESRI ArcGIS 10.3.1 software (www.esri.com).
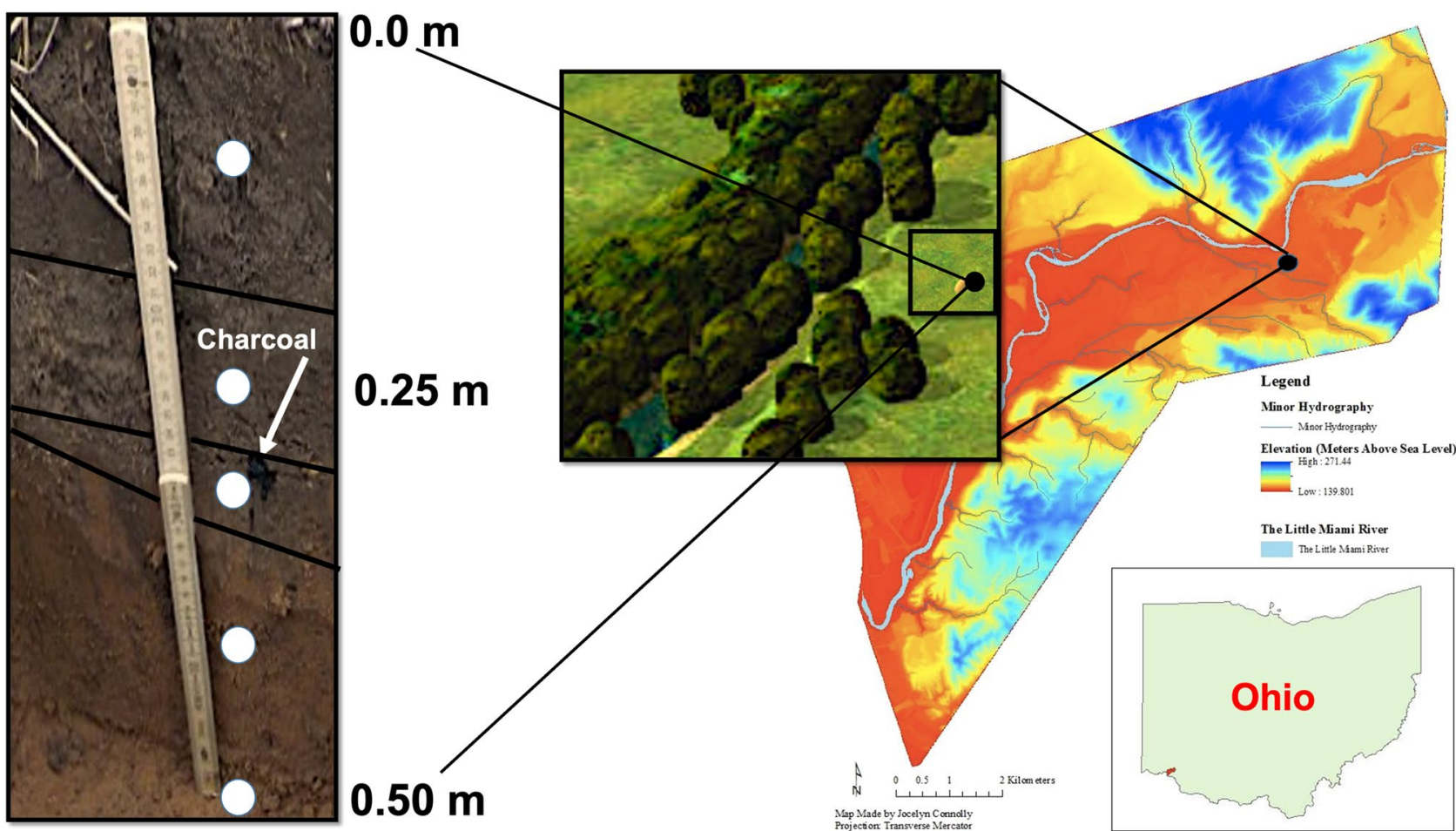

Figure 3. The location, stratigraphy, and sediment sample sites (white circles) of the Moundview village and mound site, Hamilton County, Ohio. Kenneth Barnett Tankersley used Microsoft PowerPoint for Mac Version 16.41 (www.microsoft.com) to create this figure. The GIS map was produced in ESRI ArcGIS 10.3.1 software (www.esri.com). 

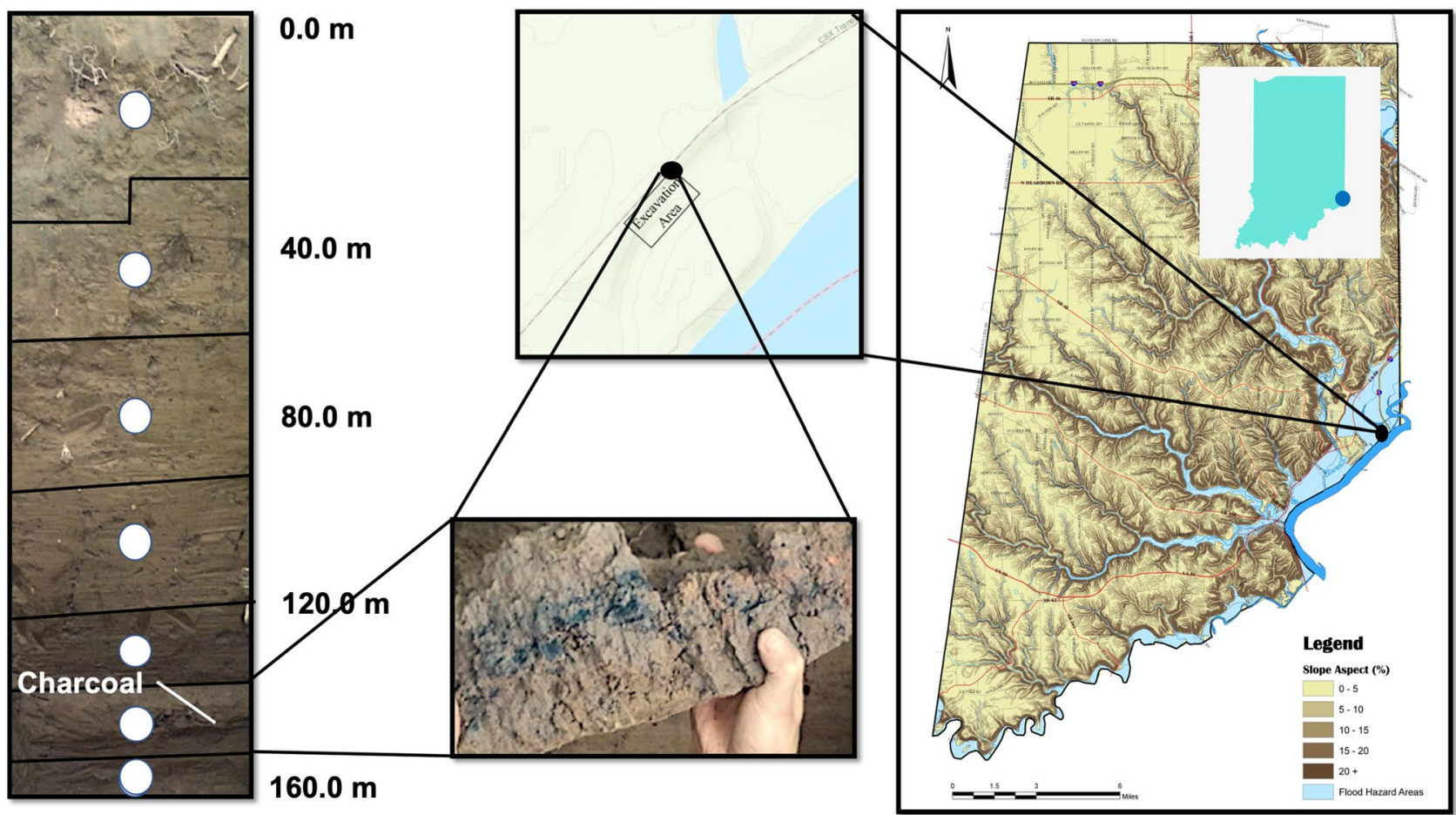

Figure 4. The location, stratigraphy, and sediment sample sites (white circles) of the Jennison-Guard village site, Dearborn County, Indiana. Kenneth Barnett Tankersley used Microsoft PowerPoint for Mac Version 16.41 (www.microsoft.com) to create this figure. The GIS map was produced in ESRI ArcGIS 10.3.1 software (www. esri.com).
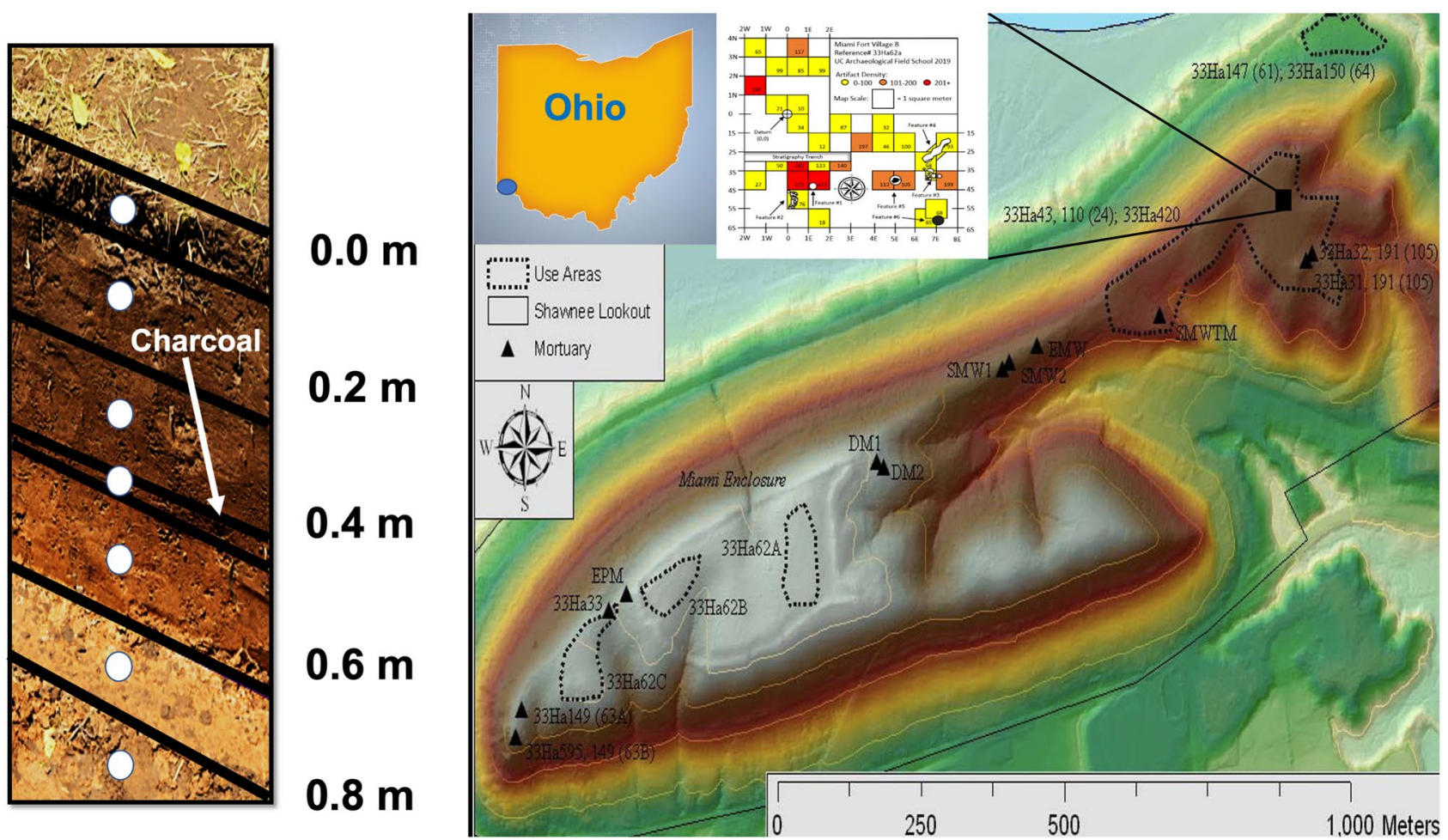

Figure 5. The location, stratigraphy, and sediment sample sites (white circles) of the Miami Fort earthworks and village site, Hamilton County, Ohio. Kenneth Barnett Tankersley used Microsoft PowerPoint for Mac Version 16.41 (www.microsoft.com) to create this figure. The GIS map was produced in ESRI ArcGIS 10.3.1 software (www.esri.com). 


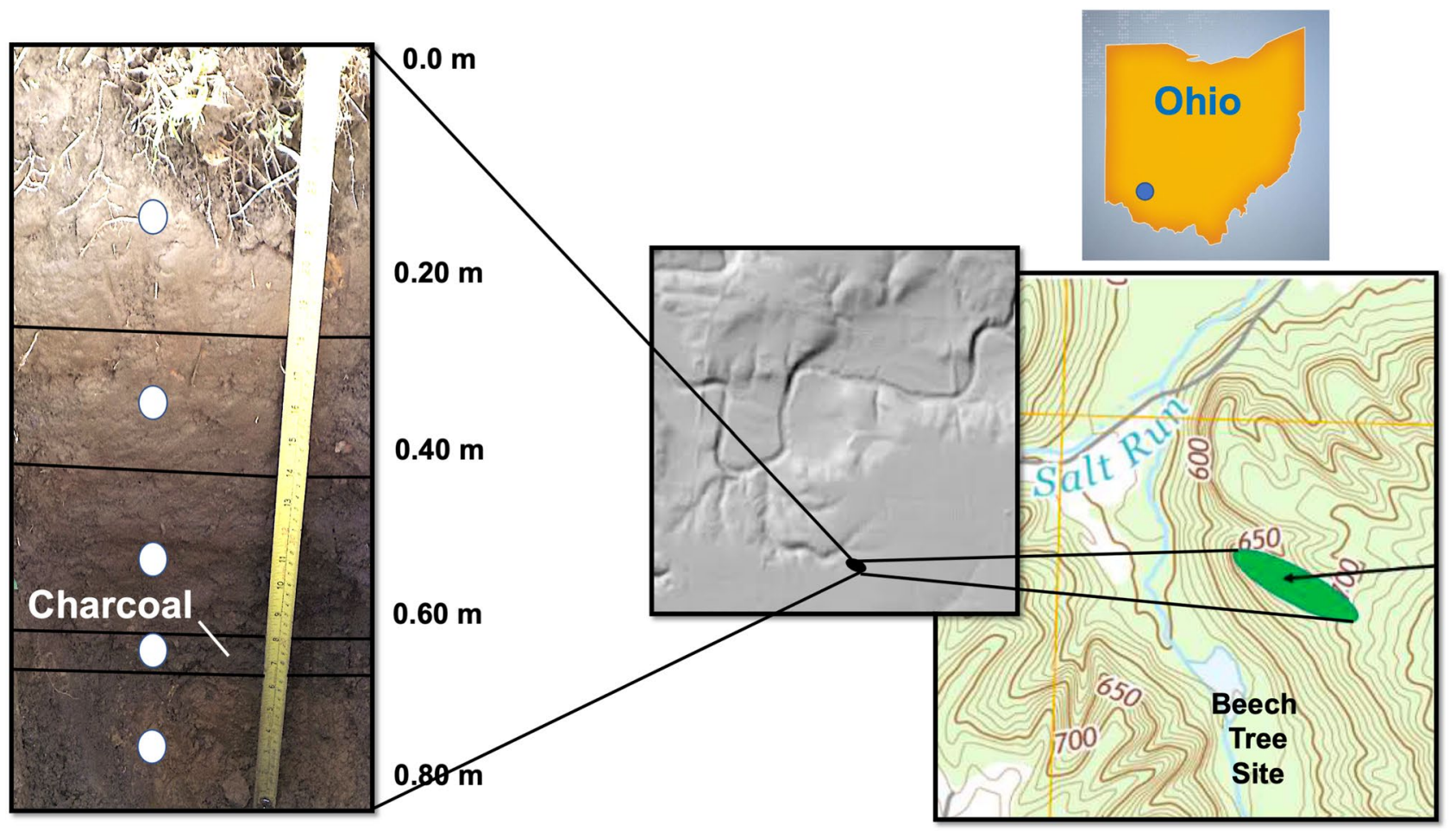

Figure 6. The location, stratigraphy, and location of sediment sample sites (white circles) of the Beech Tree village site, Clermont County, Ohio. Kenneth Barnett Tankersley used Microsoft PowerPoint for Mac Version 16.41 (www.microsoft.com) to create this figure. The GIS map was produced in ESRI ArcGIS 10.3.1 software (www.esri.com).

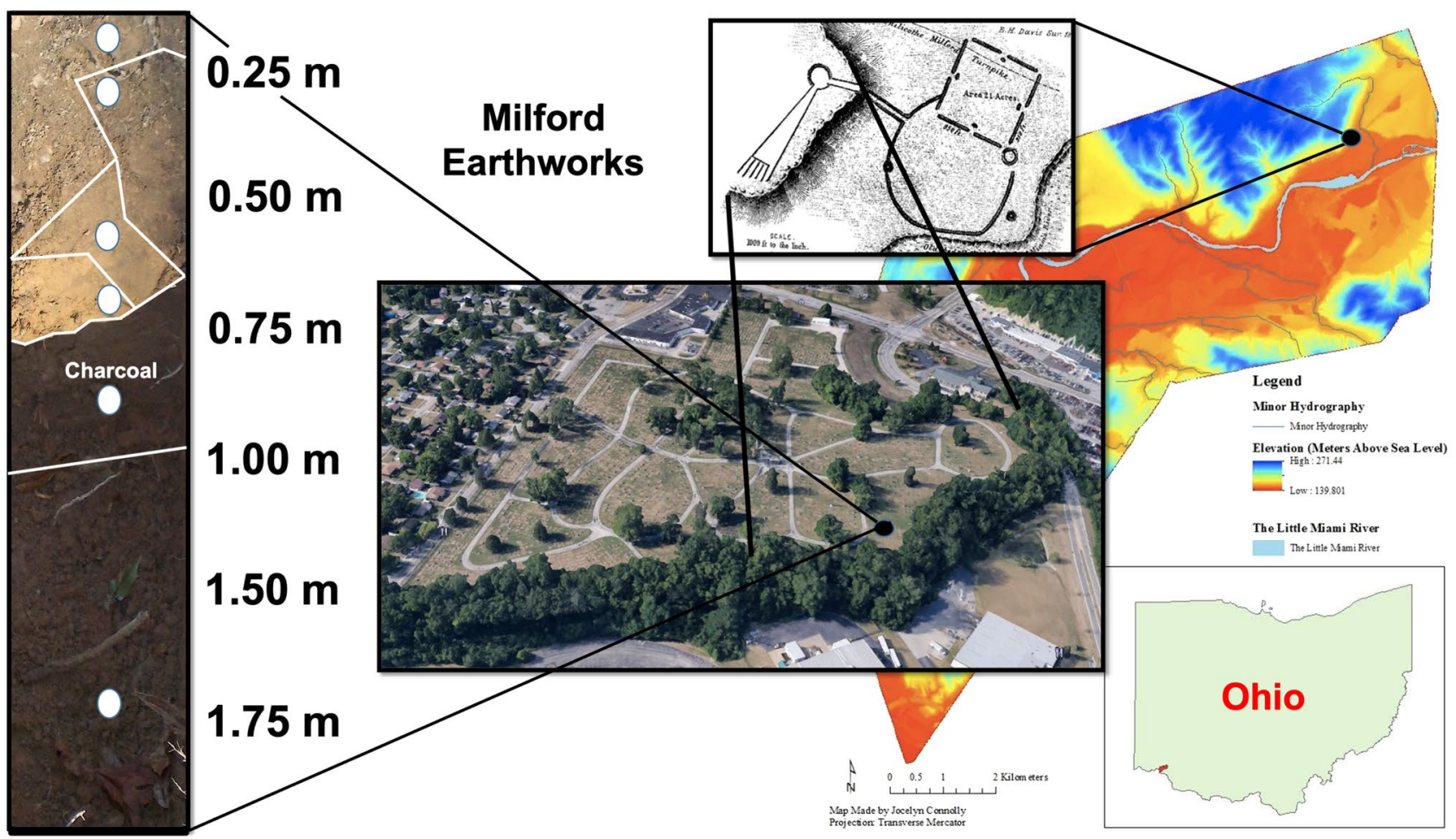

Figure 7. The location, stratigraphy, and sample sites (white circles) of the Milford Earthwork site, Clermont County, Ohio. Kenneth Barnett Tankersley used Microsoft PowerPoint for Mac Version 16.41 (www.microsoft. com) to create this figure. The GIS map was produced in ESRI ArcGIS 10.3.1 software (www.esri.com). 


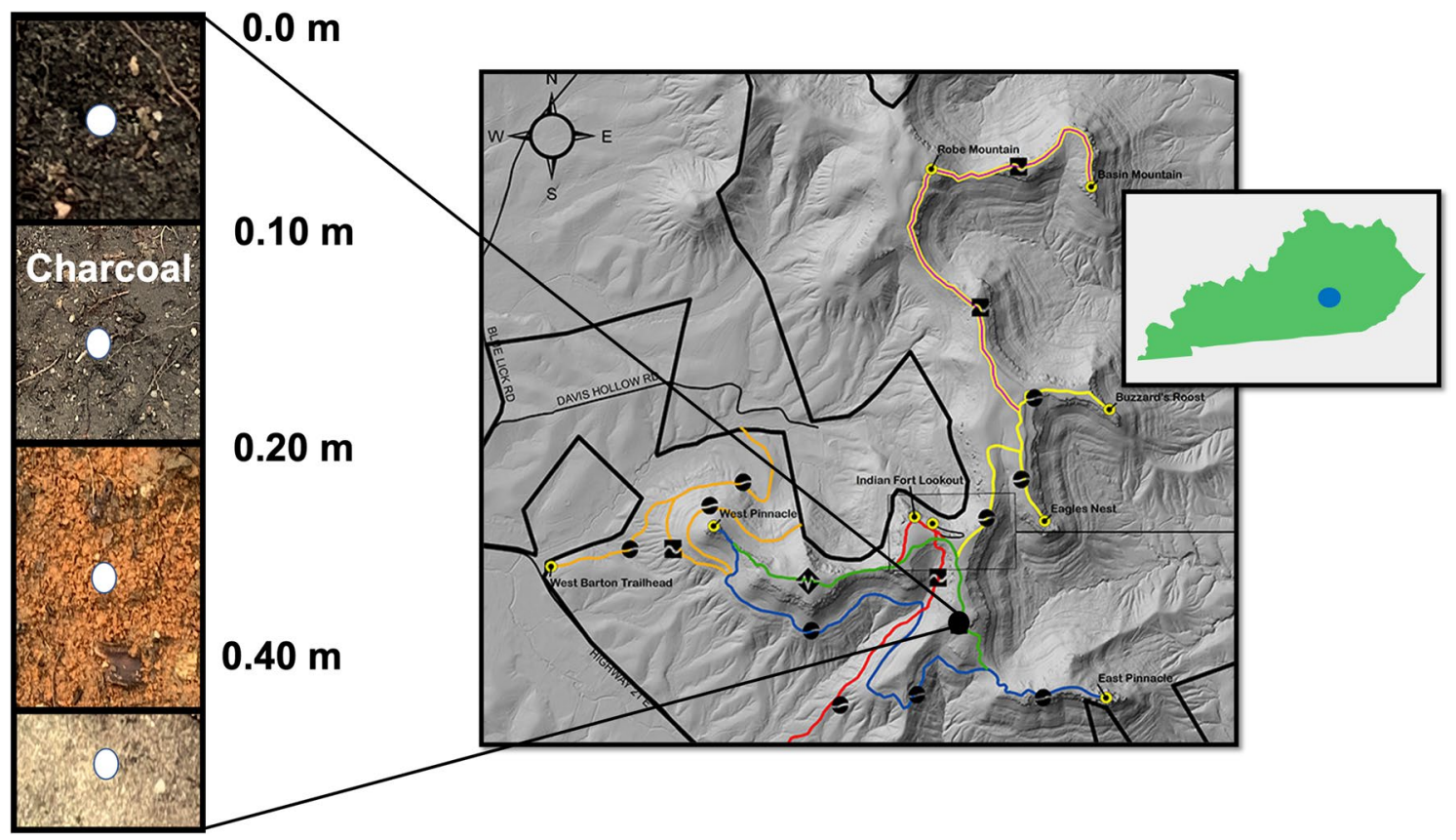

Figure 8. The location, stratigraphy, and sample site (white circles) of the Indian Fort earthworks site, Madison County, Kentucky. Kenneth Barnett Tankersley used Microsoft PowerPoint for Mac Version 16.41 (www.micro soft.com) to create this figure.

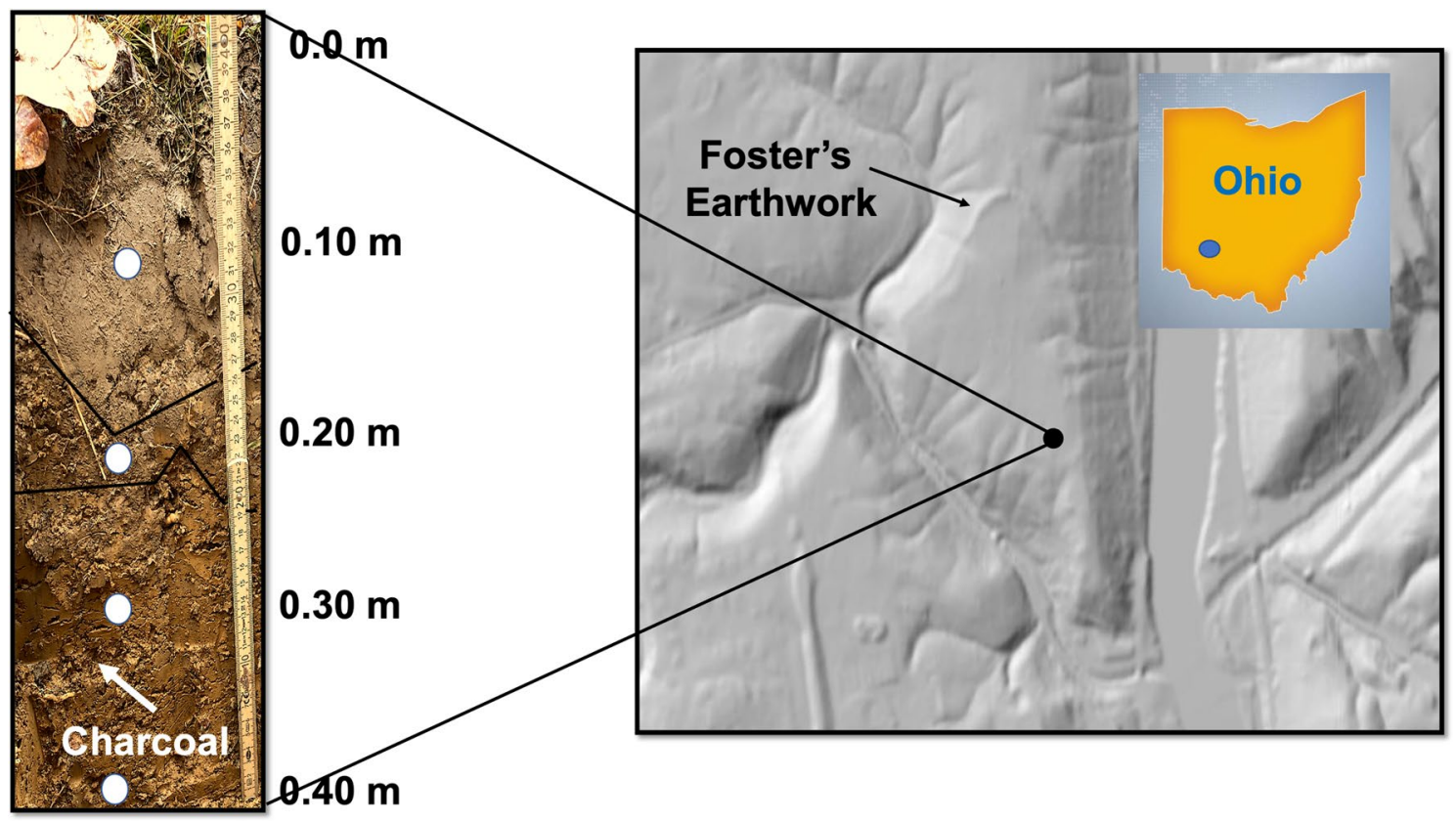

Figure 9. The location, stratigraphy, and sediment sample sites (white circles) of the Fosters Crossing earthworks site, Warren County, Ohio. Kenneth Barnett Tankersley used Microsoft PowerPoint for Mac Version 16.41 (www.microsoft.com) to create this figure. The GIS map was produced in ESRI ArcGIS 10.3.1 software (www.esri.com).

Fine gravel or coarse sand size $(<2.5 \mathrm{~mm})$ pallasites were recovered from the habitation stratum (Fig. 13). They were likely missed in previous archaeological investigations because the sediments were not screened (Section S2). The pallasites co-occurred in the habitation stratum with Fe and Si-rich microspherules. These data suggest that the Turner site meteorites represent a single local event rather than long distance procurement or trade.

At the Turner village site, Fe and Si-rich microspherules are present as black-to-clear microspheroids up to $0.4 \mathrm{~mm}$ in diameter (Fig. 14). Fe and Si-rich microspherules were also found in the habitation strata of all of the Hopewell archaeological sites sampled, ranging in size from 28.2 to $395.8 \mu \mathrm{m}$ (Sections S1, S3). SEM microscopy 


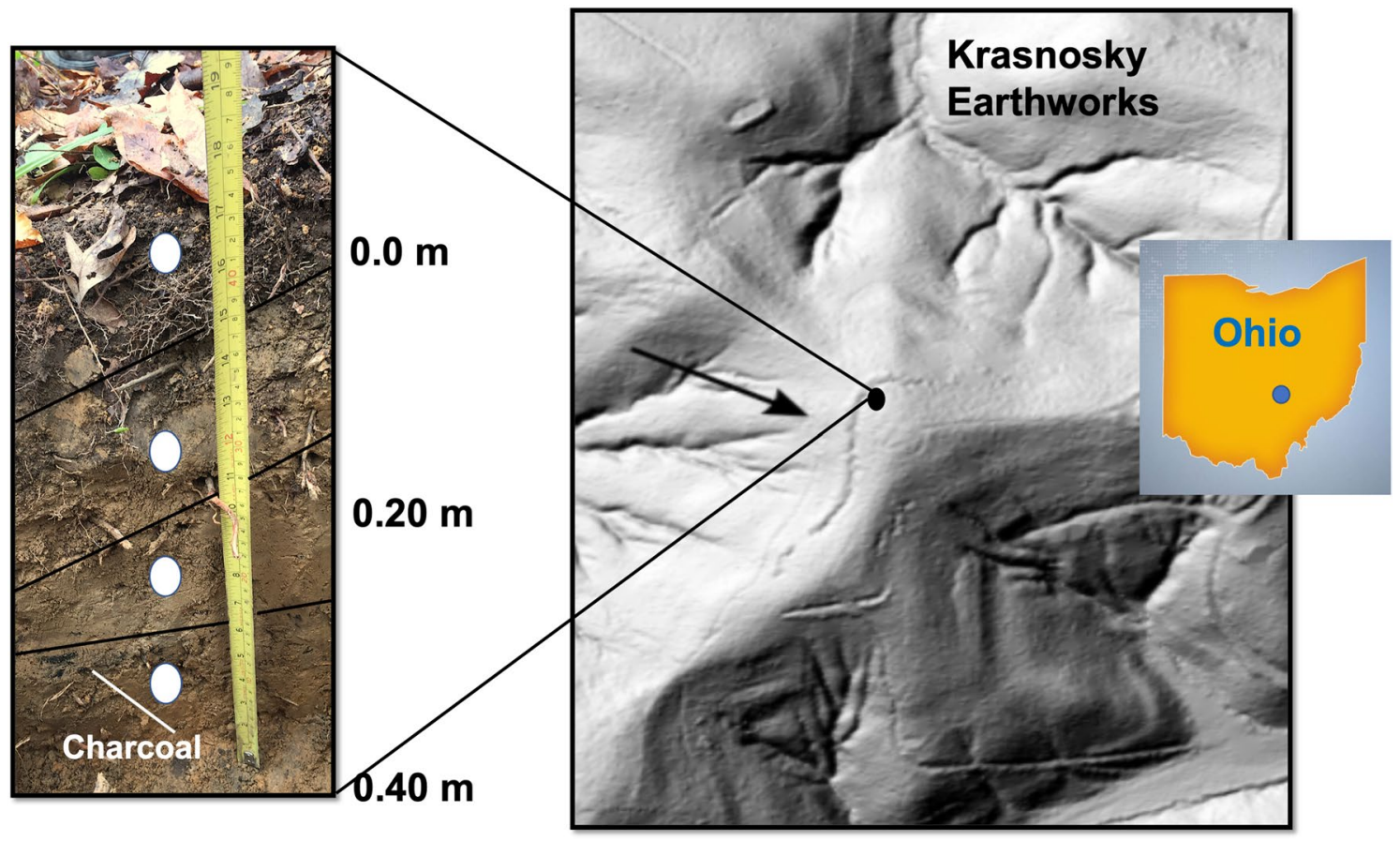

Figure 10. The location, stratigraphy, and sediment sample sites (white circles) of the Krasnosky earthworks, Hocking County, Ohio. Kenneth Barnett Tankersley used Microsoft PowerPoint for Mac Version 16.41 (www. microsoft.com) to create this figure. The GIS map was produced in ESRI ArcGIS 10.3.1 software (www.esri. com).

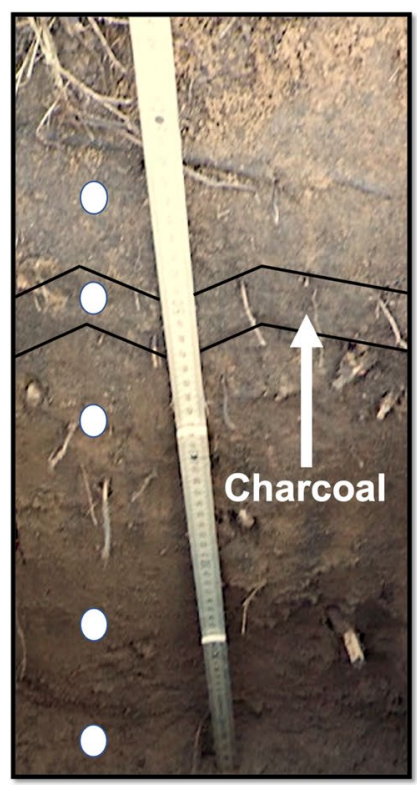

$0.0 \mathrm{~m}$

$20.0 \mathrm{~m}$

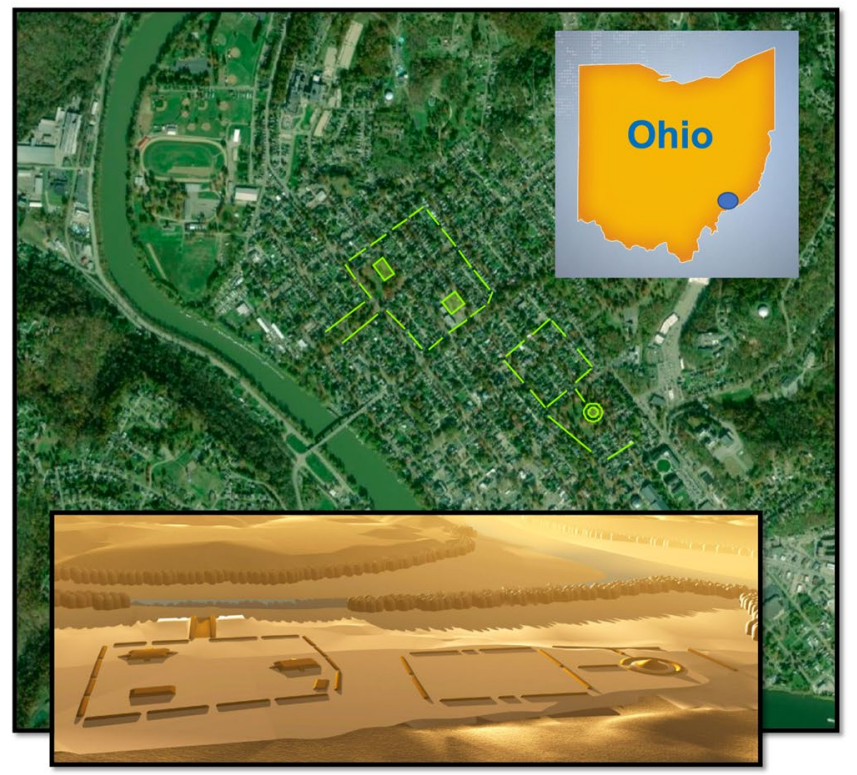

Figure 11. The location, stratigraphy, and sample sites (white circles) of the Marietta earthworks and mounds site, Washington County, Ohio. Kenneth Barnett Tankersley used Microsoft PowerPoint for Mac Version 16.41 (www.microsoft.com) to create this figure.

illustrates that the morphology and outer surface textures are distinctive of spherules of Fe and Si-rich microspherules that resulted from rapid quenching and EDS shows they are comparable in composition to pallasites (Fig. 15). They are well within the size range, morphology, and texture as those recovered from the KT boundary strata $(300 \mu \mathrm{m}$ to $1.4 \mathrm{~mm})$, the YD boundary strata $(10 \mu \mathrm{m}$ to $5.5 \mathrm{~mm})$ and the 1908 Tunguska airburst event site $(20$ to $100 \mu \mathrm{m})$, which contained sedimentary meteorites ${ }^{1,31-33}$. The Fe and Si-rich microspherules do not occur above or below the burned carbon-rich habitation strata (Fig. 16). The absence of macroscopic 


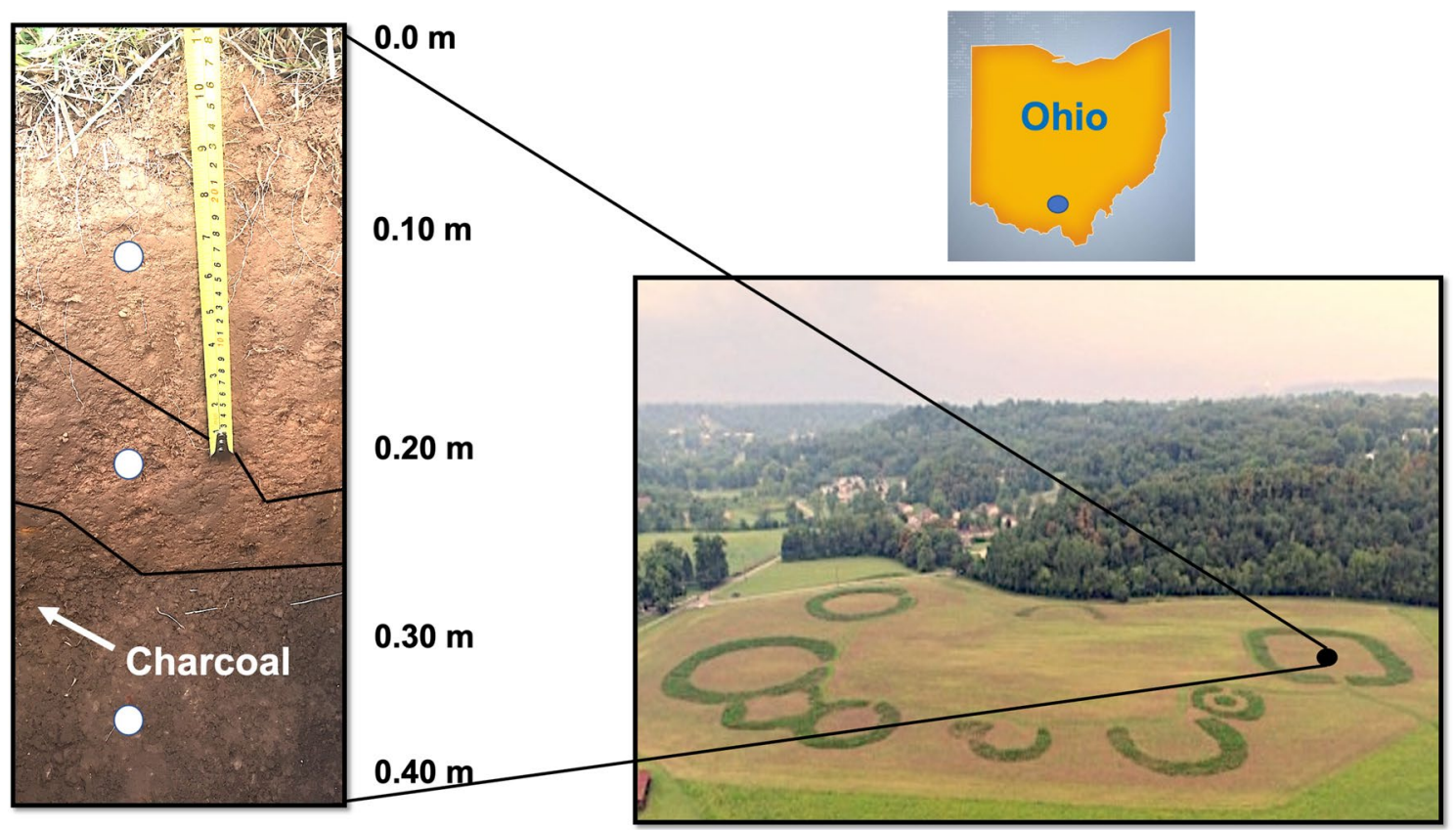

Figure 12. The location, stratigraphy, and sediment sample sites (white circles) of the Junction earthworks and mounds, Ross County, Ohio. Kenneth Barnett Tankersley used Microsoft PowerPoint for Mac Version 16.41 (www.microsoft.com) to create this figure.
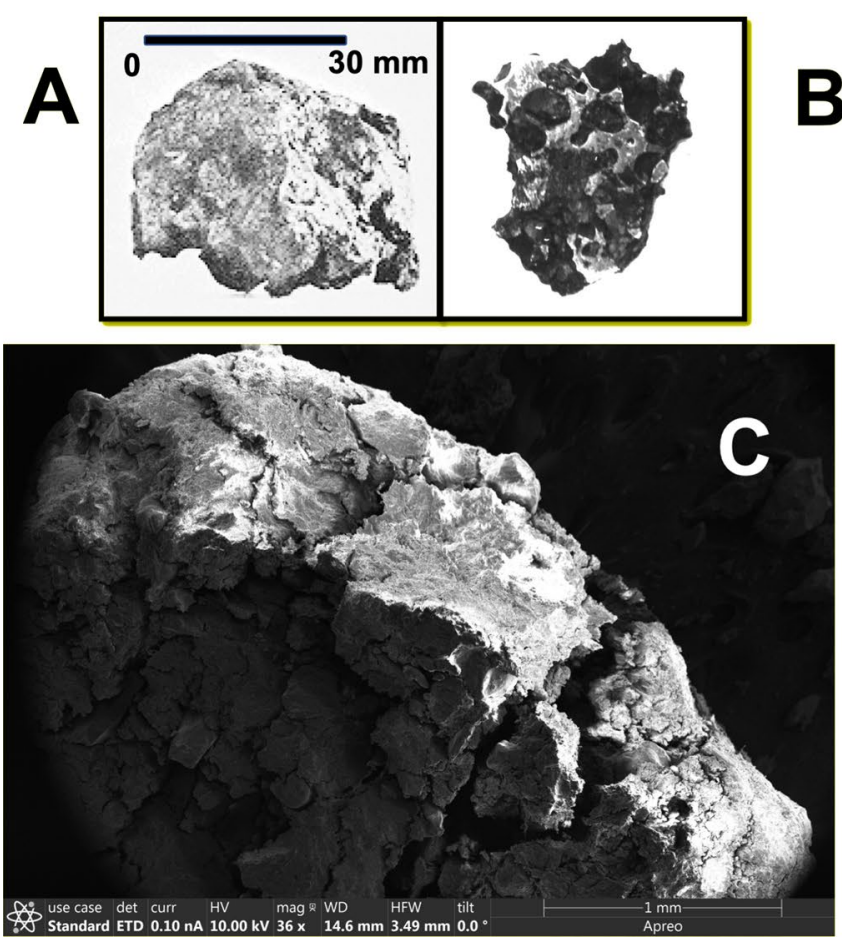

Figure 13. Pallasite meteorites from the Turner village site. (A) Pallasites excavated from the Turner village site in 1882 by Dr. Charles Louis Metz. (B) Energy Dispersive X-Ray Spectroscopy (EDS) of recently discovered pallasites from the Turner village site. (C and D) Scanning electron micrographs of recently excavated pallasites from the Hopewell habitation surface of the Turner village site. Kenneth Barnett Tankersley used Microsoft PowerPoint for Mac Version 16.41 (www.microsoft.com) to create this figure. 

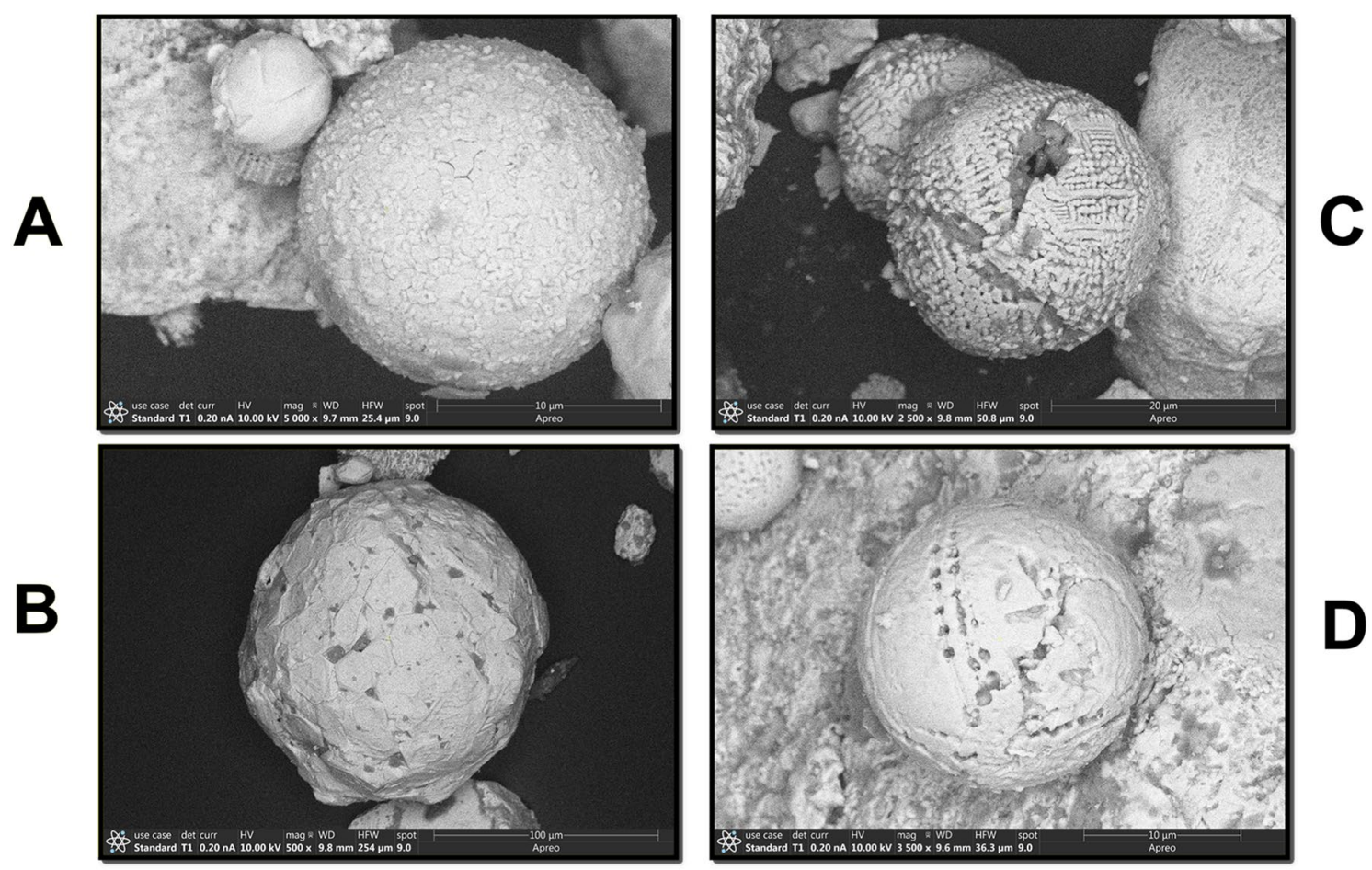

Figure 14. Scanning electron micrographs of Fe and Si-rich microspherules from the Turner earthworks and village site, Hamilton County, Ohio. Kenneth Barnett Tankersley used Microsoft PowerPoint for Mac Version 16.41 (www.microsoft.com) to create this figure.
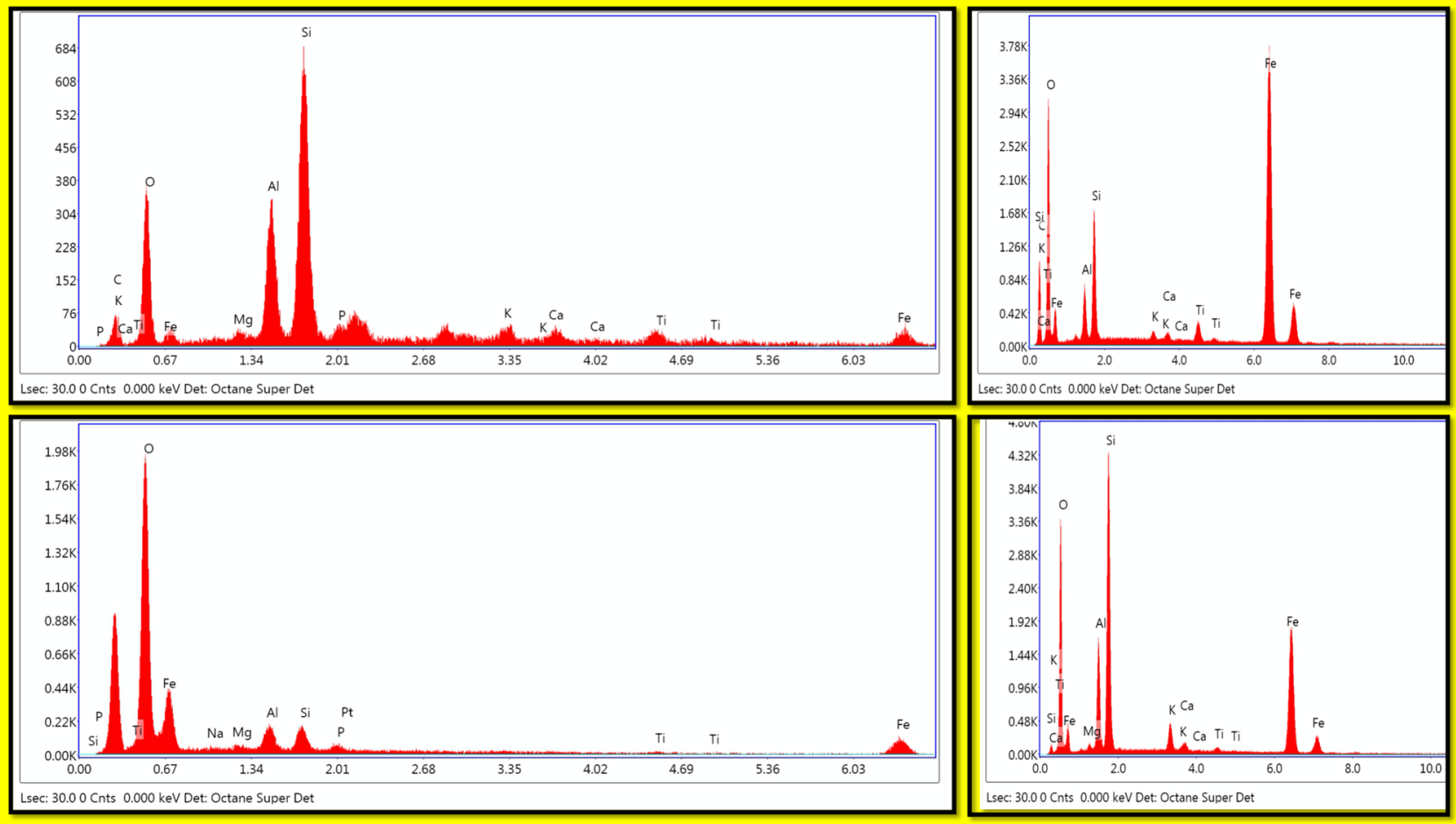

Figure 15. Energy Dispersive X-Ray Spectroscopy (EDS) of exemplary Fe and Si-rich microspherules from the Turner earthworks and village site, Hamilton County, Ohio. Kenneth Barnett Tankersley used Microsoft PowerPoint for Mac Version 16.41 (www.microsoft.com) to create this figure. 


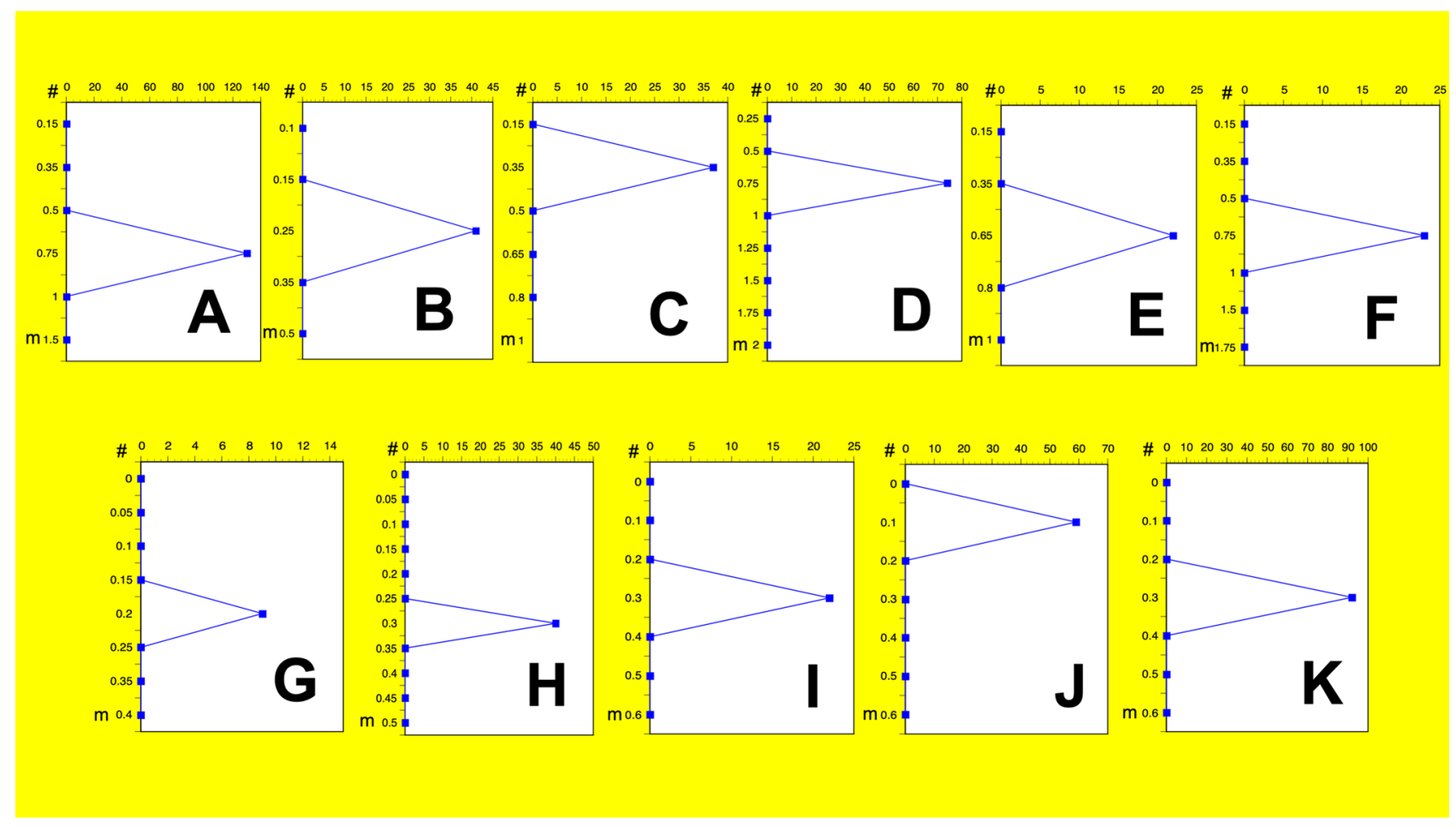

Figure 16. Quantity of Fe and Si-rich microspherules by depth (m): (A) Turner earthworks and village, Ohio; (B) Moundview village and mound, Ohio; (C) Miami Fort hilltop earthworks, Ohio; (D) Jennison-Guard village site, Indiana, (E) Beech Tree village, Ohio; (F) Milford earthworks, Ohio; (G) Indian Fort Mountain earthworks, Kentucky; (H) Foster's Crossing earthwork, Ohio, (I) Krasnosky earthworks, Ohio; (J) Junction earthworks, Ohio; (K) Marietta earthworks and mounds, Ohio. Kenneth Barnett Tankersley used Microsoft PowerPoint for Mac Version 16.41 (www.microsoft.com) to create this figure.

shock-metamorphic impactites such as shocked quartz, shatter cones, impact breccia, or evidence of melting of the country rock sedimentation cover suggest that the airburst event generated less than two gigapascals of pressure.

A positive Ir anomaly (1.08 ppb) was found in the burned carbon-rich Hopewell habitation stratum of the Turner site (Section S3). Ir in the Turner site sediments is $50 \times$ as high as the natural crustal abundance $(0.02 \mathrm{ppb})^{34}$. Of the eleven Hopewell archaeological sites sampled, Ir levels from burned carbon-rich habitation strata ranged from 0.10 to $1.08 \mathrm{ppb}$. The level of $\operatorname{Ir}(1.08 \mathrm{ppb})$ in the habitation strata of the Turner and the nearby $(5 \mathrm{~km})$ Moundview site is approximately twice that commonly found in meteorites $(0.5 \mathrm{ppb})^{34,35}$. Although the level of Ir in the habitation strata of the Turner and Moundview sites is not as elevated as that found in the KT boundary strata $(3.9 \mathrm{ppb})$, it is well within the range reported from YD boundary strata $(<0.5 \text { to } 3.8 \mathrm{ppb})^{1,34}$.

Positive Pt anomalies ( 0.53 to $6.23 \mathrm{ppb}$ ) were found in ten of the eleven Hopewell archaeological sites sampled (Figs. $17,18,19)$. The Pt level of the Turner site $(6.23 \mathrm{ppb})$ is $12 \times$ the natural crustal abundance $(0.5 \mathrm{ppb})$ and well within the range reported for the KT $(4.0$ to $8.0 \mathrm{ppb})$ and YD $(0.3$ to $65.6 \mathrm{ppb})$ boundary strata ${ }^{36,37}$. The Pt abundance in the burned charcoal-rich habitation level of the Krasnosky earthwork ( $0.53 \mathrm{ppb})$ fell within the level of the crustal abundance of $0.5 \mathrm{ppb}^{37}$. Positive Pt and Ir anomalies were only found in the burned carbonrich habitation strata of the Hopewell sites sampled (Section S3). Pt and Ir levels were below detection limits above and below the habitation strata.

The habitation surface of all eleven of the Hopewell sites sampled were fire-hardened, carbon-rich, and contained masses of wood charcoal (Section S3). The burned, carbon-rich nature of Hopewell habitation strata in the Ohio River valley was first described during the late nineteenth century ${ }^{28,38,39}$. At the Turner site, the remains of Hopewell habitation structures were found on fire-hardened, ash covered surfaces with post-molds filled with wood charcoal ${ }^{30}$. At Foster's Crossing in Warren County, Ohio, the habitation surface was described as having been exposed to extreme heat. The stratum was labeled as "vitreous" with "great masses of slag" resembling "that from a blast furnace," and limestone that had been thermally reduced to lime ${ }^{38-40}$.

We found similar burned features at the Miami Fort site in Hamilton County, Ohio and the Jennison-Guard site in Dearborn County, Indiana (Section S3). The remains of burned Hopewell structures had been swept into piles of carbonized timbers and thatch, fire-hardened daub, and thermally damaged artifacts. Limestone from the burned structures was reduced to calcium oxide, which indicates a temperature of $>765^{\circ} \mathrm{C}$. The widespread occurrence of burned wooden structures and carbon-rich, heat-altered habitation surfaces at all eleven of the Hopewell sites examined suggests widespread synchronous fires resulting from a catastrophic cosmic airburst event. 

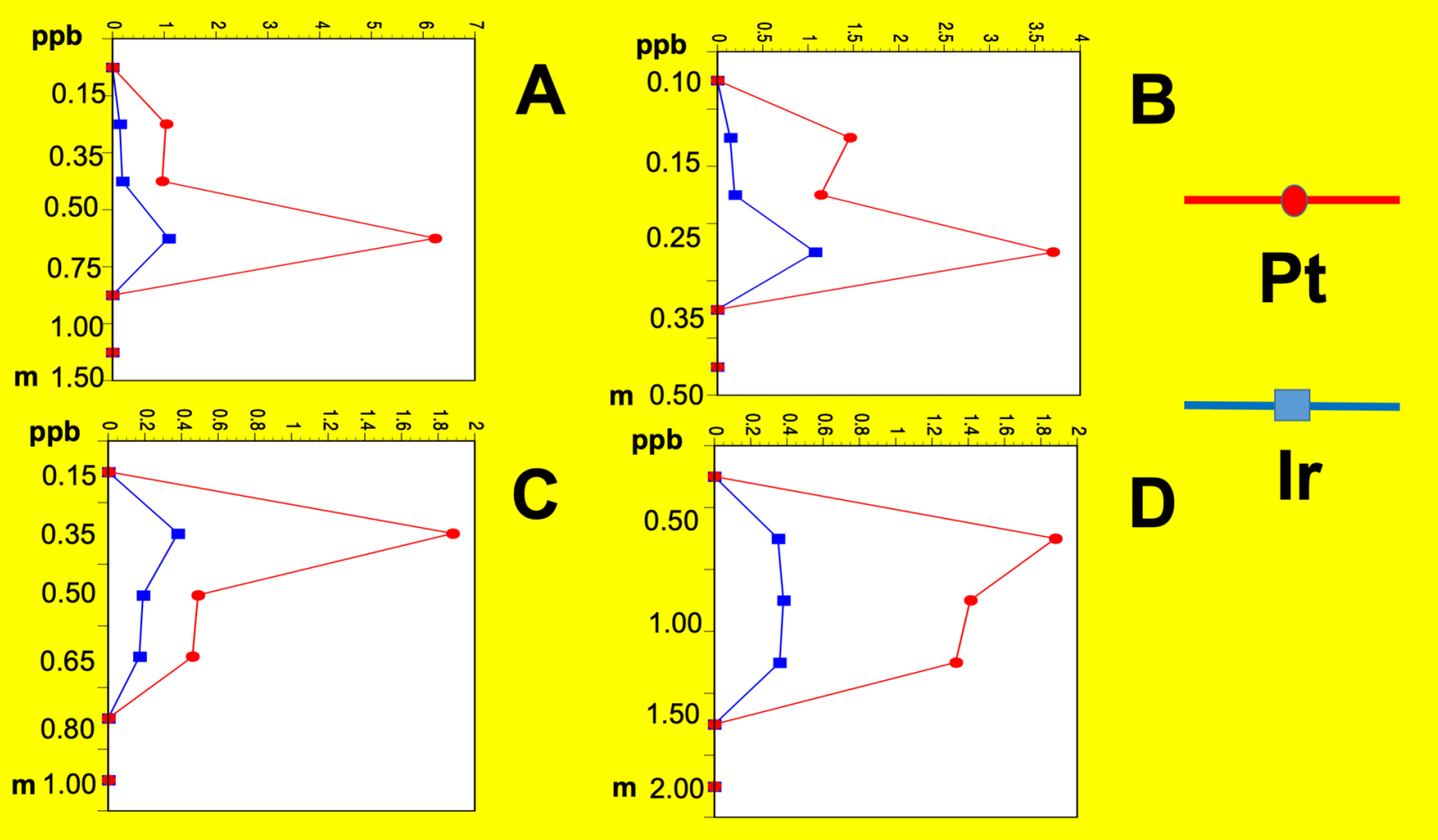

Figure 17. Positive Ir and Pt anomalies from the burned carbon-rich strata on Hopewell archaeological sites in the Ohio River valley: (A) Turner earthworks and village, Ohio; (B) Moundview village and mound, Ohio; (C) Miami Fort hilltop earthworks, Ohio; (D) Jennison-Guard village site, Indiana. Kenneth Barnett Tankersley used Microsoft PowerPoint for Mac Version 16.41 (www.microsoft.com) to create this figure.

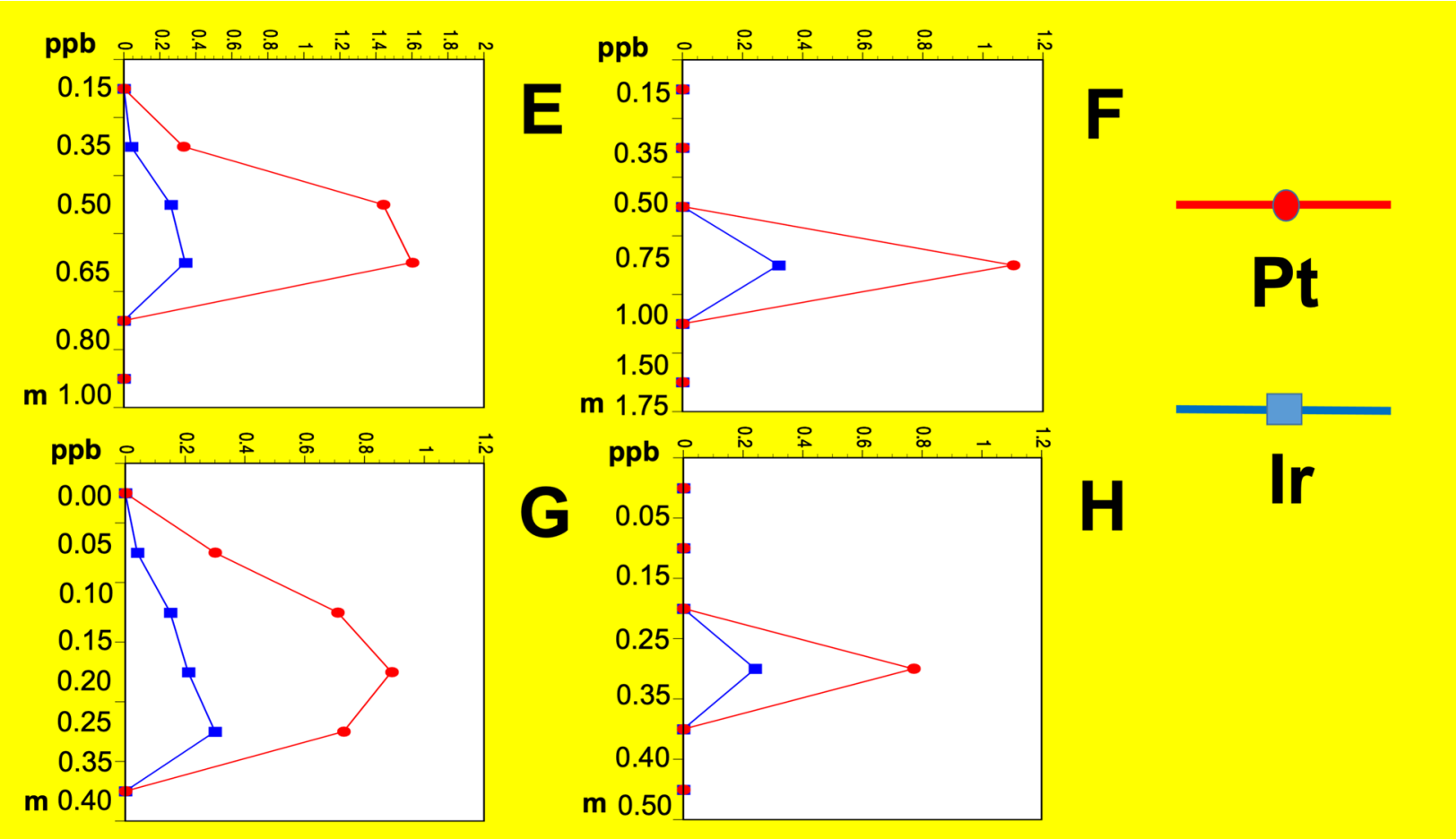

Figure 18. Positive Ir and Pt anomalies from the burned carbon-rich strata on Hopewell archaeological sites in the Ohio River valley: (E) Beech Tree village, Ohio; (F) Milford earthworks, Ohio; (G) Indian Fort Mountain earthworks, Kentucky; (H) Foster's Crossing earthwork, Ohio. Kenneth Barnett Tankersley used Microsoft PowerPoint for Mac Version 16.41 (www.microsoft.com) to create this figure.

In order to evaluate the impact of the airburst event on vegetation, stable carbon isotope values were obtained 


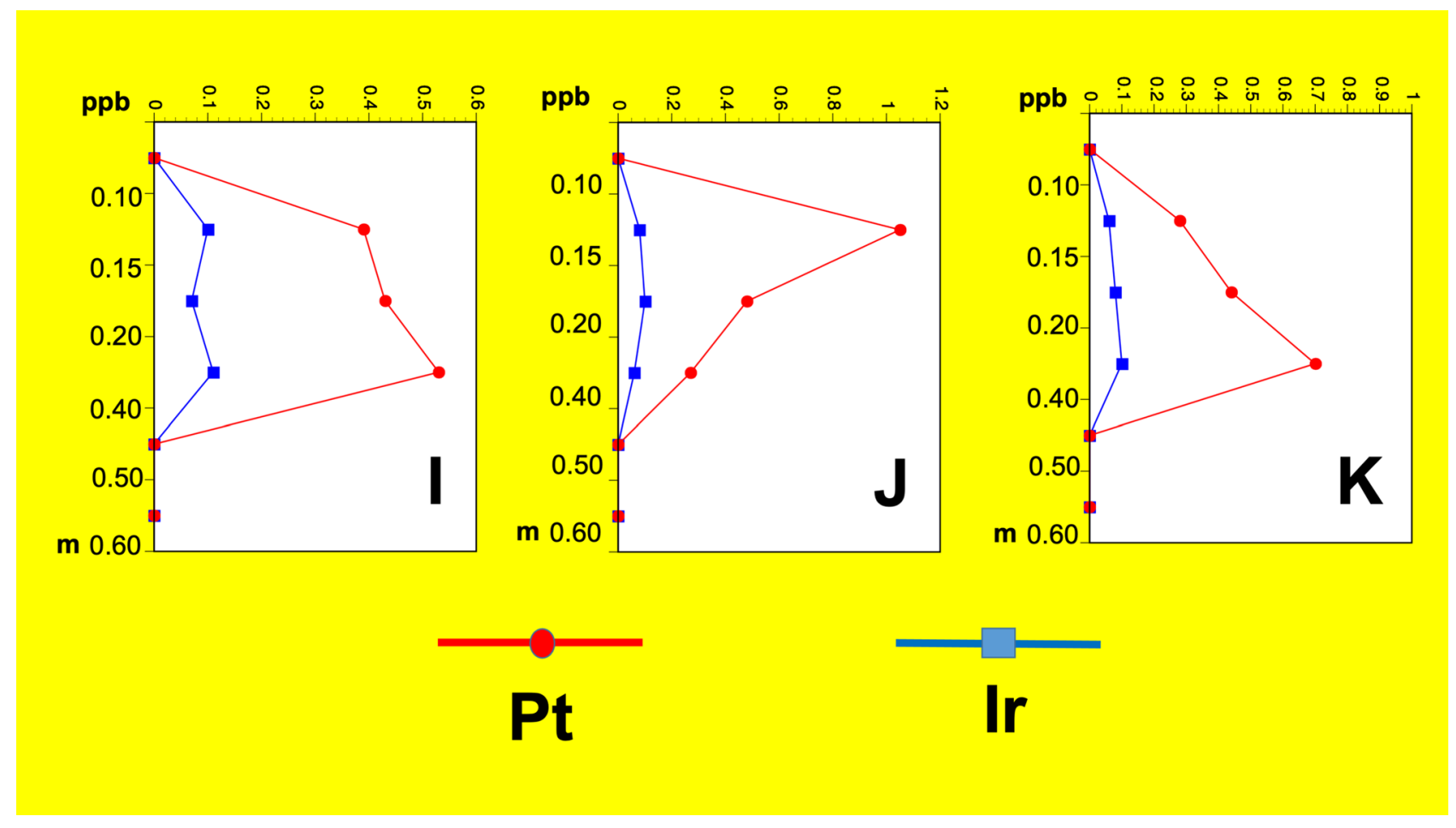

Figure 19. Positive Ir and Pt anomalies from the burned carbon-rich strata on Hopewell archaeological sites in the Ohio River valley: (I) Krasnosky earthworks, Ohio; (J) Junction earthworks, Ohio; (K) Marietta earthworks and mounds, Ohio. Kenneth Barnett Tankersley used Microsoft PowerPoint for Mac Version 16.41 (www.micro soft.com) to create this figure.

on bulk organic matter obtained from Hopewell reservoir sediments at the Miami Fort site (Section S3) ${ }^{41}$. The reservoir strata ranged in age from the beginning of the Middle Woodland cultural period, $100 \mathrm{BCE}$, to modern. The $\delta{ }^{13} \mathrm{C}$ values of bulk organic matter show that the vegetation composition varied through time. The $\delta{ }^{13} \mathrm{C}$ isotope values from the Hopewell sediments ranged -23.76 to $-24.77(\mathrm{~N}=3)$ with an average of $-24.24+0.5 \%$. The $\delta{ }^{13} \mathrm{C}$ values of bulk organic matter from the post-Hopewell sediments ranged from to -24.38 to -26.45 $(\mathrm{N}=17)$ with an average of $-25.33+0.5 \%$. Stable carbon isotope values indicate a landscape dominated by $\mathrm{C} 3$ vegetation throughout the late Holocene with a significant change in $\mathrm{C} 3$ vegetation indicated by a $\delta^{13} \mathrm{C}$ value of -23.76, which was obtained from a stratum dating to the time of the Hopewell airburst (Fig. 20).

Chronological context. Radiocarbon and typological dating were used to provide a chronological context for the Hopewell comet airburst related proxies and evaluate their synchroneity. Typologically, distinctive Hopewell artifacts were defined on the basis of similarities in their form, method of manufacture, raw material, style, and use. Temporally diagnostic artifacts, which date between $100 \mathrm{BCE}$ and $400 \mathrm{CE}$, were found in the Hopewell habitation strata of all eleven of the archaeological sites examined (Section S3). They include Hopewell earthenware pottery and figurines, microblades and microblade cores, mica effigies, and Lowe-flared and Snyders bifaces ${ }^{23}$.

Radiocarbon ages were obtained for the Turner, Jennison-Guard, Miami Fort, Marietta, and Indian Fort Mountain sites (Fig. 21). Radiocarbon ages were calibrated to produce probability density functions using Bayesian statistics with credible intervals assigned to each date (Section S3). We used the IntCal20 calibration curve in the OxCal 4.4 computer program for Bayesian statistical analysis. Radiocarbon ages from the Turner $(\mathrm{N}=7)$ and Jennison-Guard $(\mathrm{N}=8)$ sites are considered high-quality because they were obtained directly from the burned carbon-rich habitation strata, they have the highest number of ages per stratum, the smallest degrees of uncertainties, and they are associated with a plethora of temporally distinctive artifacts ${ }^{42}$. The age of the airburst-proxy stratum at the Turner site is $1712-1612$ B.P. (239-339 CE) with a probability of $95 \%$. The age of the airburst-proxy stratum at the Jennison-Guard site is $1691-1541$ B.P. (259-410 CE) with a probability of $95 \%$. The Turner and Jennison-Guard sites radiocarbon ages overlap at one standard deviation.

The radiocarbon ages from the Marietta $(\mathrm{N}=4)$, Miami Fort $(\mathrm{N}=7)$, and Indian Fort Mountain $(\mathrm{N}=2)$ sites are well-dated, but they have greater degrees of uncertainties. The age of the airburst-proxy stratum at the Marietta site is $1704-1539$ B.P. (246-401 CE) with a probability of $95 \%$. The age of the airburst-proxy stratum at the Miami Fort site is $1867-1310$ B.P. (116-641 CE) with a probability of $95 \%$. The age of the airburst-proxy stratum at the Indian Fort Mountain site post-dates 1990-1706 B.P. (post-dates 41 BCE-245 CE) with a probability of 95\%. Although the Marietta, Miami Fort, and Indian Fort Mountain radiocarbon ages are not considered highquality, they do overlap at one standard deviation with the Turner and Jennison-Guard sites radiocarbon ages. Twenty-eight radiocarbon ages place the Hopewell airburst proxies at 1699-1567 B.P. (252-383 CE). 


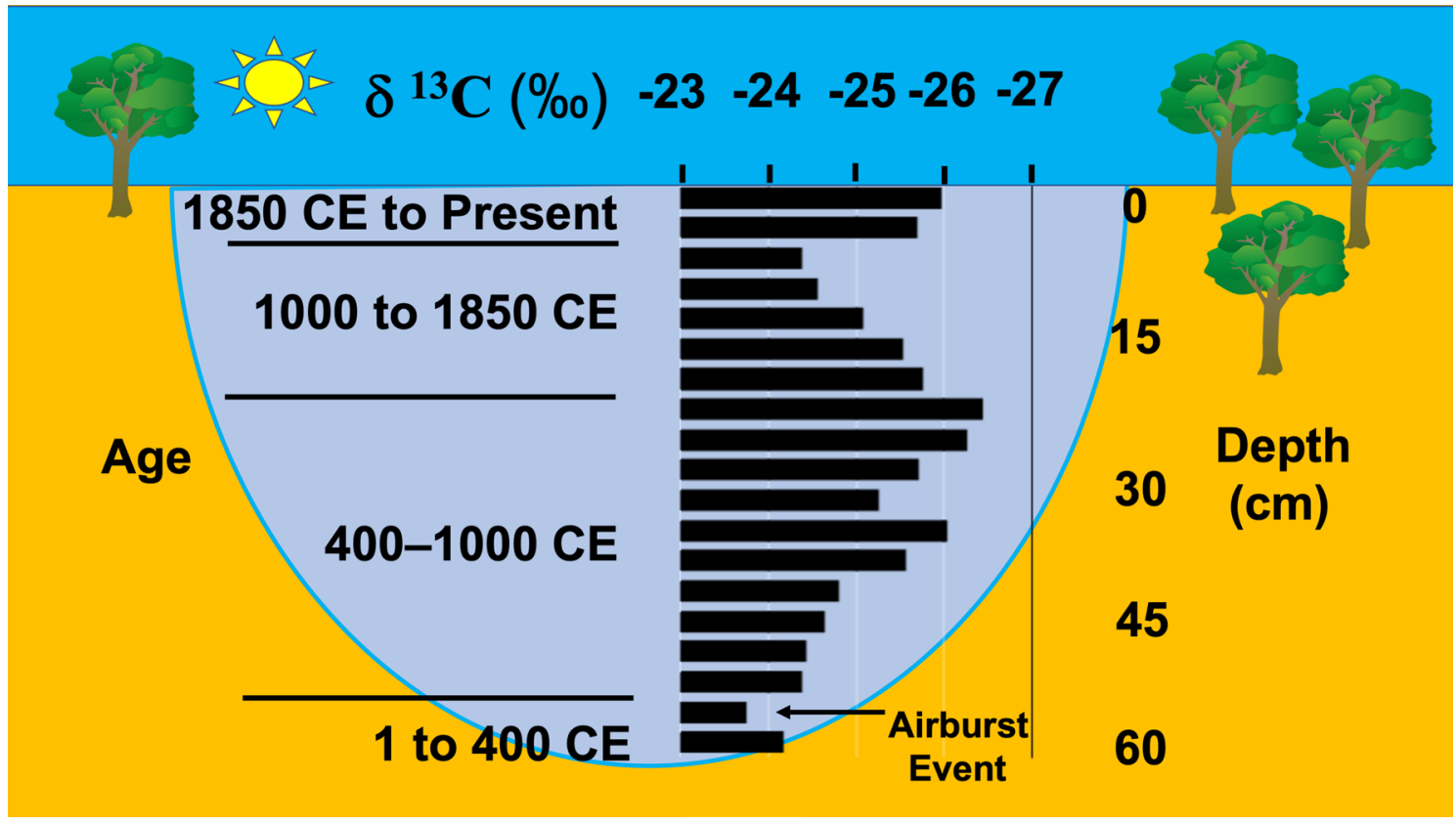

Figure 20. Chronostratigraphy of a Hopewell reservoir at the Miami Fort earthworks and village site showing the delta ${ }^{13} \mathrm{C}$ values and ages by depth. Kenneth Barnett Tankersley used Microsoft PowerPoint for Mac Version 16.41 (www.microsoft.com) to create this figure.

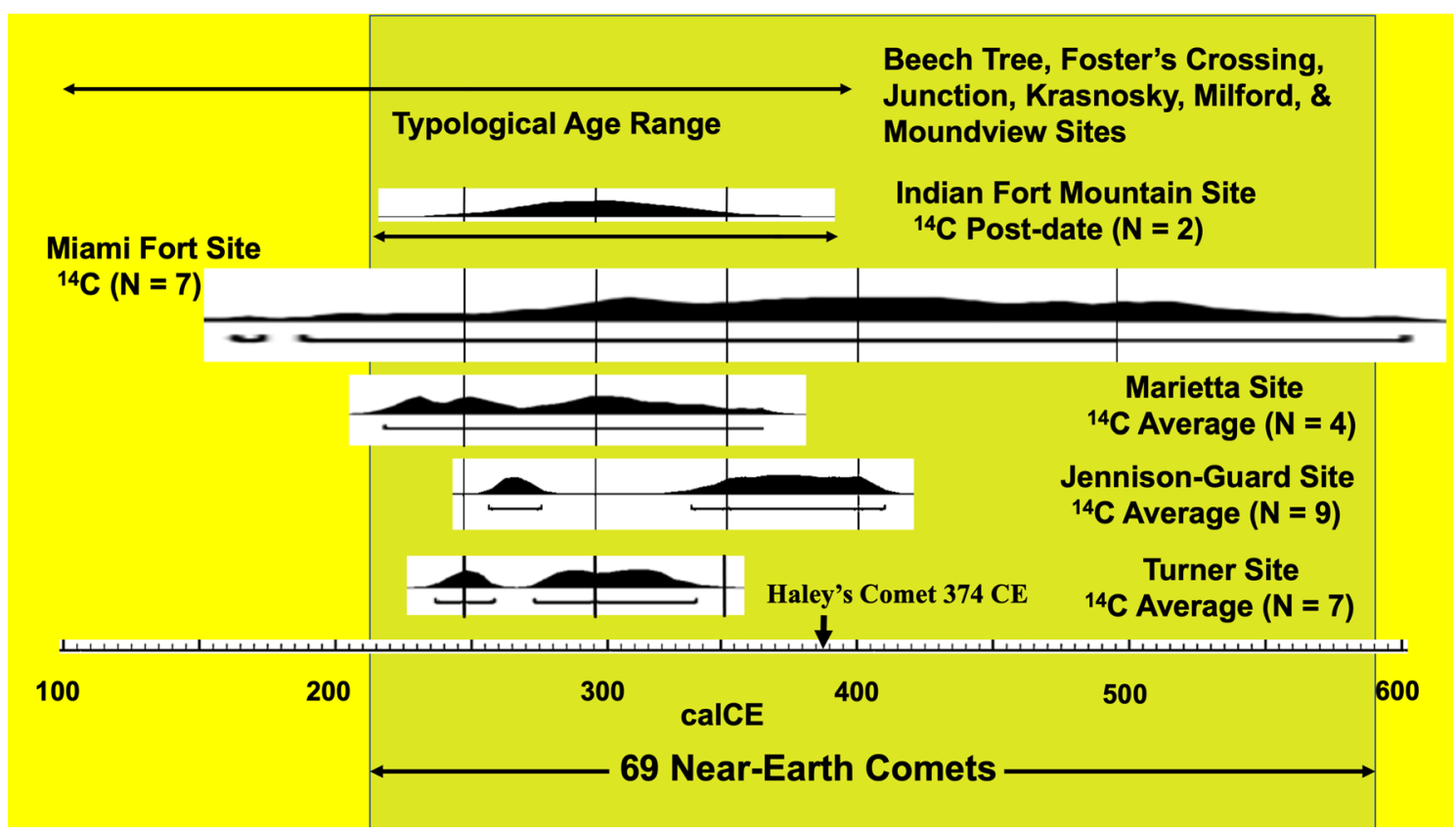

Figure 21. Typological age range and Bayesian adjustments of the radiocarbon ages averages for the Hopewell archaeological study sites using the IntCal20 calibration curve in the OxCal 4.4 computer program relative to the timing of 69 near-Earth comets. Kenneth Barnett Tankersley used Microsoft PowerPoint for Mac Version 16.41 (www.microsoft.com) to create this figure.

\section{Discussion}

Meteorites, the highest levels of Ir and Pt, and the largest Fe and Si-rich microspherules cooccur in the burned, charcoal-rich Hopewell habitation stratum of the Turner site. These independent proxies suggests that the Turner site was at or near the epicenter of the airburst (Figs. 22, 23, 24). The levels of Ir and Pt and the diameter of Fe and Si-rich microspherules decrease with increasing distance from the epicenter. The initial impact appears to have an orientation of northeast to southwest. This orientation is comparable to the orientation of the comet shaped Milford Earthwork (Fig. 25). Pt, Ir, and microspherule residual plumes extended in low concentrations well to 


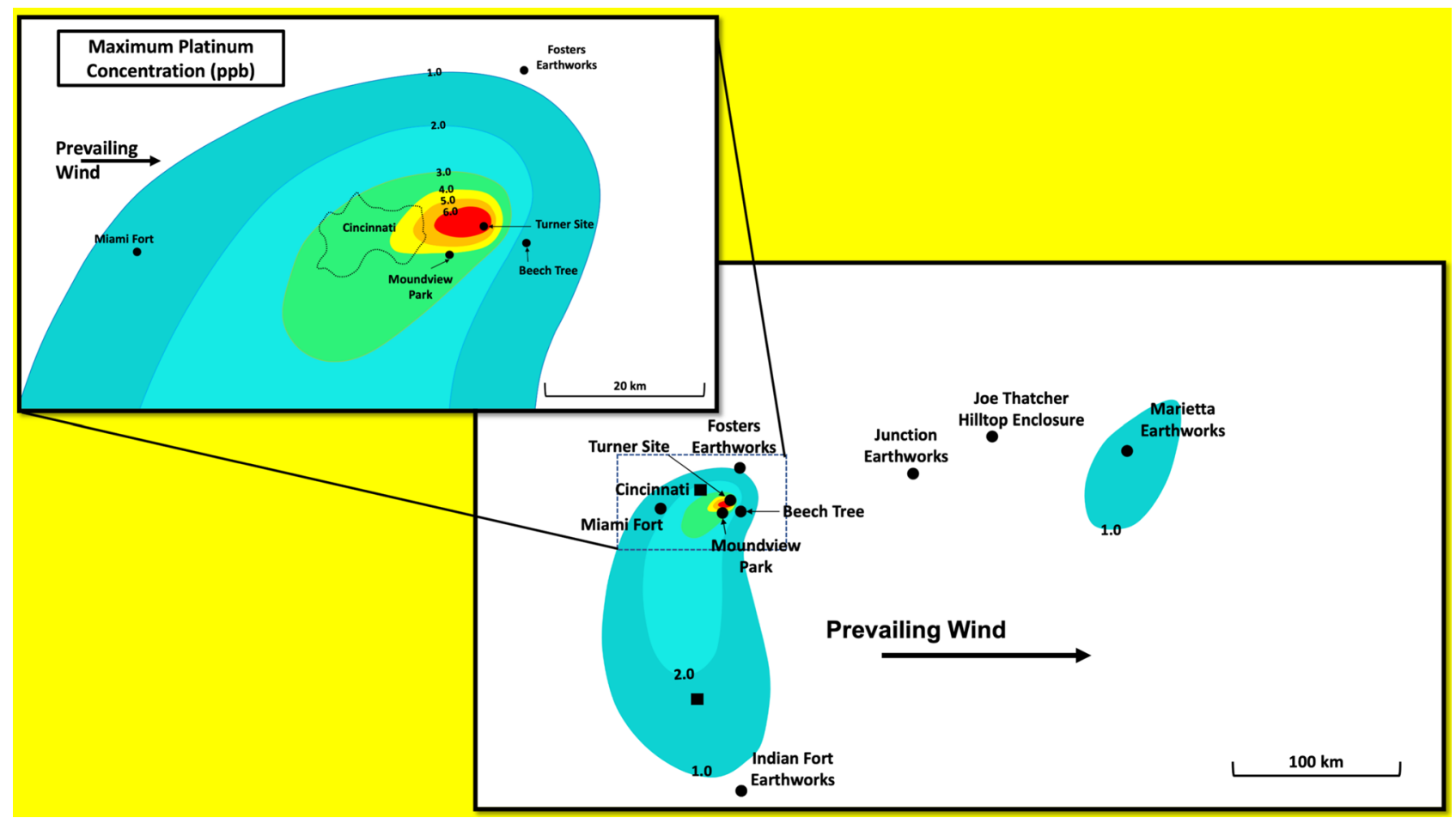

Figure 22. Geographic distribution of a positive platinum anomaly. Stephen Meyers and Stephanie Meyers used Microsoft PowerPoint for Mac Version 16.41 (www.microsoft.com) to create this figure.

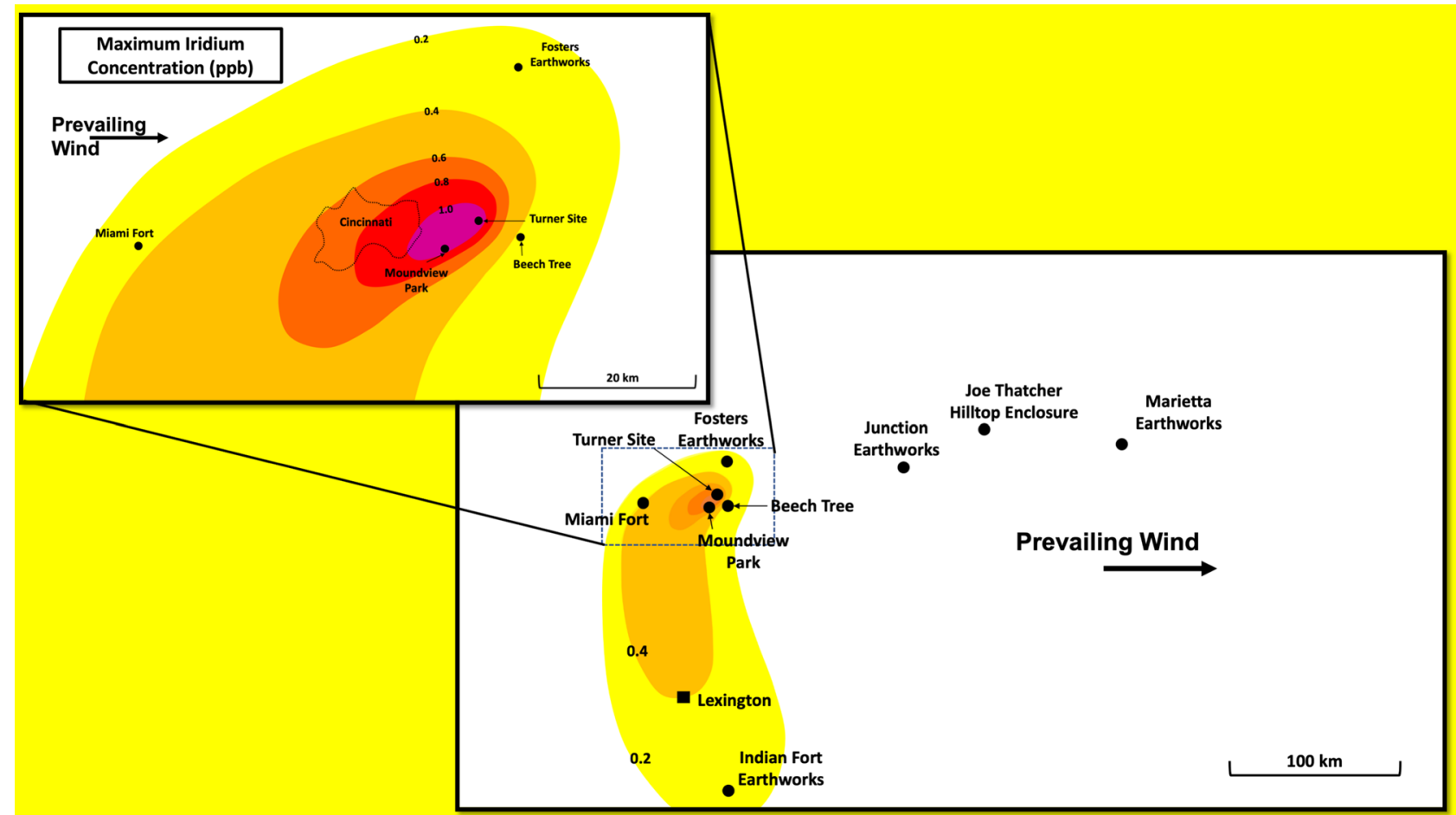

Figure 23. Geographic distribution of a positive iridium anomaly. Stephen Meyers and Stephanie Meyers used Microsoft PowerPoint for Mac Version 16.41 (www.microsoft.com) to create this figure. 


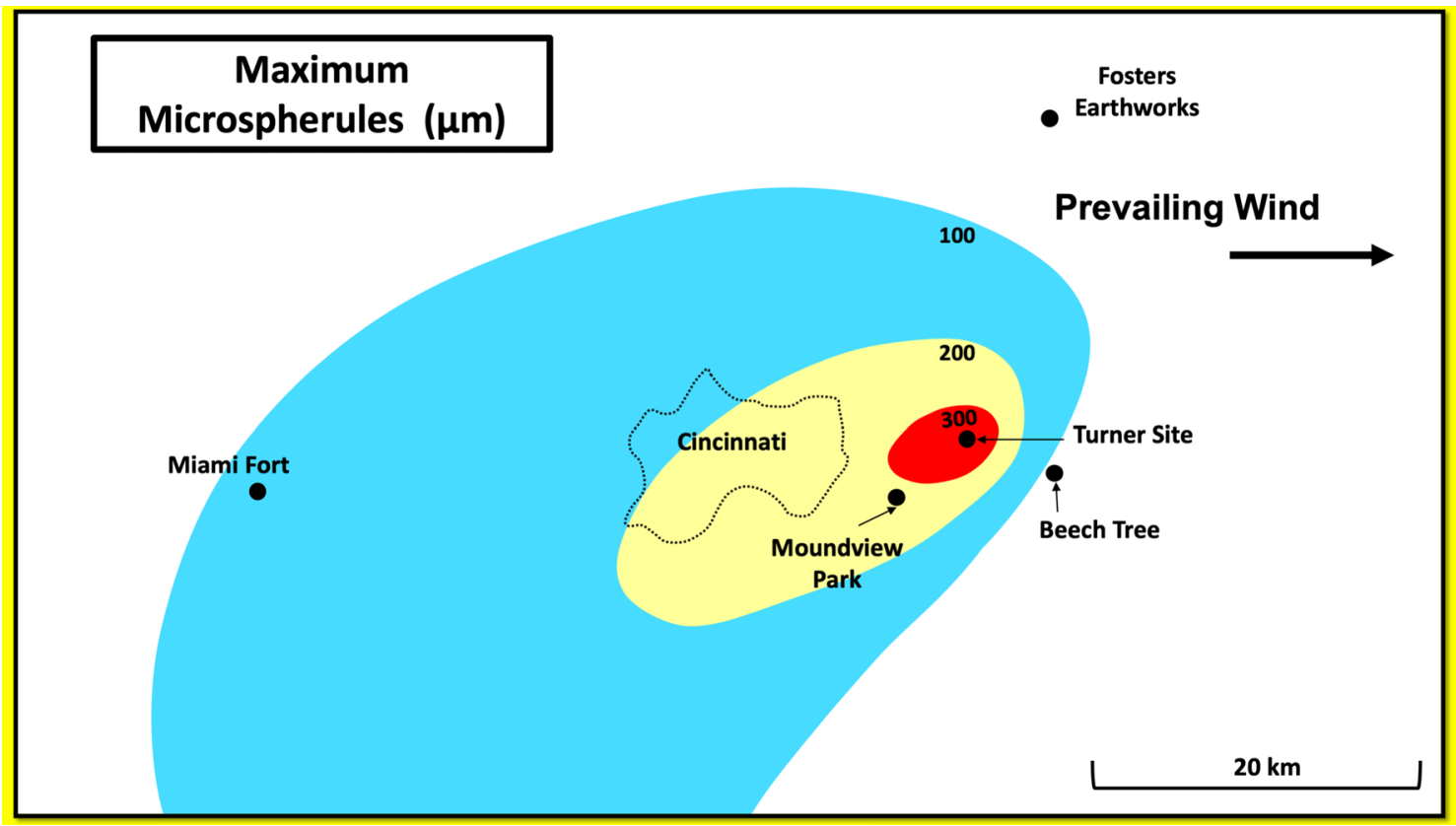

Figure 24. Geographic distributions of the maximum size of microspherules. Stephen Meyers and Stephanie Meyers used Microsoft PowerPoint for Mac Version 16.41 (www.microsoft.com) to create this figure.

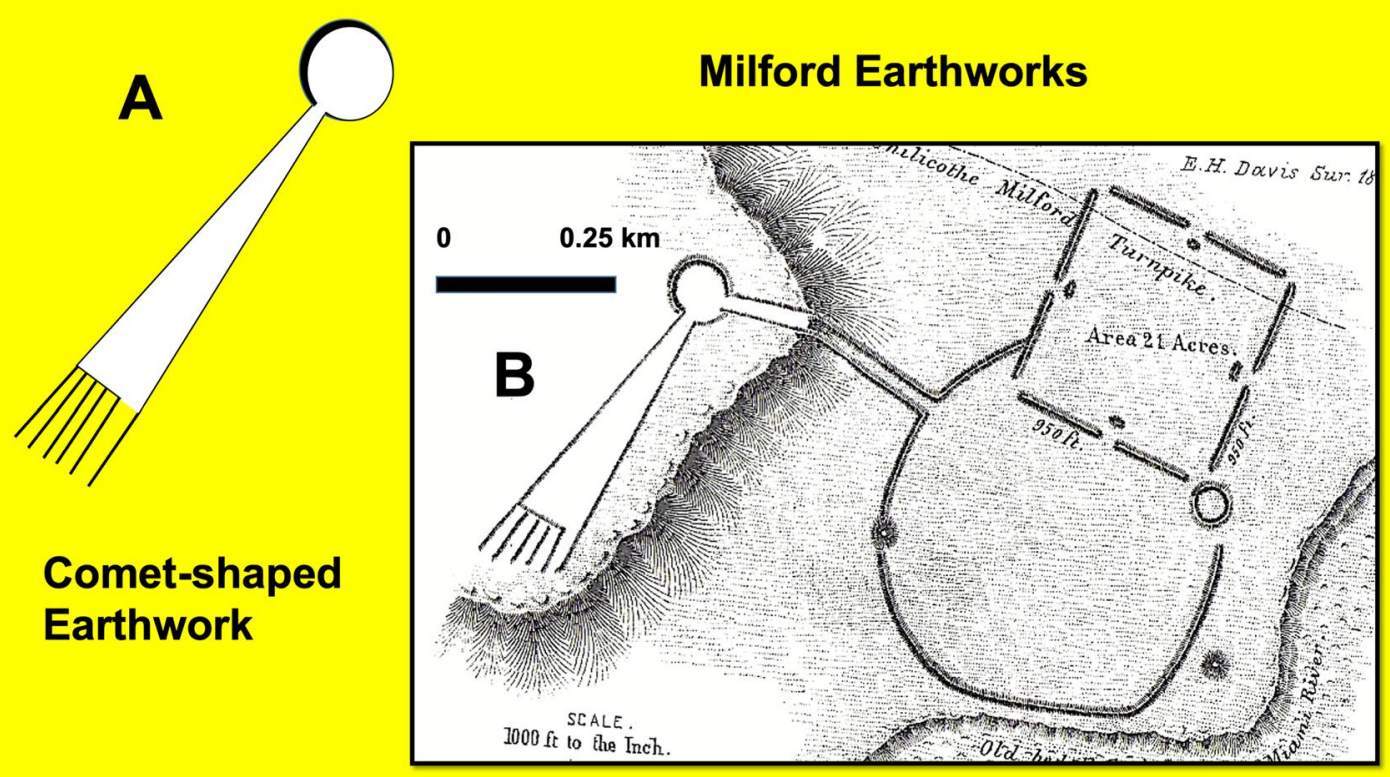

Figure 25. Comet-shaped Milford earthwork based on E. G. Squier and E. H. Davis' 1848 Ancient Monuments of the Mississippi Valley Comprising the Results of Extensive Original Surveys and Explorations (Smithsonian Institution, Washington D.C.). Kenneth Barnett Tankersley used Microsoft PowerPoint for Mac Version 16.41 (www.microsoft.com) to create this figure.

the south at Indian Fort Mountain, Madison County, Kentucky. The orientation of the residual plumes in a more north-to-south orientation, rather than the original northeast to southwest trend, was likely produced by the prevailing west-to-east weather fronts that commonly pass across North America.

The core area of the airburst event is estimated to be $\sim 500 \mathrm{~km}^{2}$ based on Hopewell habitation strata with positive $\mathrm{Pt}$ anomalies $>3.0 \mathrm{ppb}$, positive Ir anomalies $>0.6 \mathrm{ppb}$, and microspherules $>200 \mu \mathrm{m}$ in diameter. The total area of the Ohio River valley affected by the airburst event is estimated to be $\sim 14,900 \mathrm{~km}^{2}$ based on Hopewell habitation strata with positive Pt anomalies $>1.0 \mathrm{ppb}$ and positive Ir anomalies $>0.2 \mathrm{ppm}$. This area includes the Indian Fort earthwork in Madison County, Kentucky, but excludes the Marietta earthworks in Washington 
County, Ohio. The high positive Pt anomaly in the Hopewell habitation strata of the Marieta earthworks site suggests that multiple comet fragments likely impacted the Ohio River valley. Thus, the Turner village site is most likely one of many Hopewell comet airburst epicenters across the Midwest.

It is unknown whether or not there were human casualties from the airburst. Following the airburst event, Hopewell people collected meteorites, which they used in the production of objects that were interred with human remains. A Hopewell earthwork was constructed in the shape of a comet in the immediate vicinity of the airburst epicenter (Fig. 25). Hopewell symbolic systems continue to be used by descendant tribes in the telling of their oral histories, which refer to an ancient cosmic event ${ }^{43-45}$.

The Myaamia observed an ancient comet, which they call Lenipinšia, a horned serpent that crossed the sky and dropped rocks on the land before plummeting into the river ${ }^{45}$. The Shawnee word Tekoomse refers to a comet known as the Sky Panther ${ }^{46}$. The Haudenosaunee say that the Sky Panther, Dajoji, has the power to tear down forests ${ }^{47}$. Ottawa oral histories describe a day when the sun fell from the sky, and the Huron and Wyandot recount a time when a black cloud rolled across the sky and was destroyed with a fiery dart by $\mathrm{Hehnoh}^{48}$. These millennial generational oral histories are deeply rooted in eye-witnessed events ${ }^{49}$.

\section{Conclusion}

The Hopewell comet airburst event adds to our growing body of knowledge of catastrophic cosmic events, which led to cultural downturns in ancient complex, sedentary, and agricultural-based societies. Multiple independent comet airburst event proxies have been found on eleven Hopewell archaeological sites in the Ohio River valley, which have typological and calibrated radiocarbon age ranges of 1699-1567 B.P. (252-383 CE). This time period coincides with historically documented near-Earth comets and occurs immediately prior to the cultural downturn of the Hopewell. The airburst event may have created mass confusion resulting in an upheaval of the social interaction sphere.

Near-Earth comets have been increasing through time (up to 2 per year) and those with an orbital period of $\sim 10,000$ years may remain within a planetary system between 5,000 and 15,000 years ${ }^{50}$. Thus, we expect to find more examples of such events in the archaeological record. The cultural impact and geographic extent of ancient cosmic airbust events can only be evaluated and interpreted through interdisciplinary investigations that include chronostratigraphy, petrography, and geochemical analyses. These methods, if carried out rigorously, will provide a greater understanding of ancient catastrophic cosmic airburst events, their impact on complex human societies, and their frequency not only in the Western Hemisphere, but elsewhere in the world.

\section{Methods}

Sediment samples were obtained from archaeological units and trenches, which were hand excavated by the authors (Section S3). Stable carbon isotope samples were extracted using a split-spoon, 5-cm diameter solid sediment core and a hand-operated drop-hammer. Soil horizons and stratigraphic boundaries were defined in the field on the basis of color, texture, structure, and pedogenic features and confirmed in the lab with particle size analysis and Munsell soil color charts ("Results" section). The location of all archaeological features, sediment cores, excavation units, and trenches were recorded in the field using a hand-held GPS (Section S1). AMS radiocarbon samples and XRD samples were collected from excavation units, trenches, and solid sediment.

cores (Section S3). AMS radiocarbon ages were determined at Beta Analytic and the Center for Applied Isotope Studies at the University of Georgia (Section S3). Radiocarbon ages were calibrated and Bayesian statistical analysis was done using the IntCal20 calibration curve in the OxCal 4.4 computer program (https://c14.arch.ox. ac.uk/oxcal.html). Scanning electron microscopy (SEM) and energy dispersive spectrometry (EDS/EDAX) was accomplished in the Advanced Materials Characterization Center at the University of Cincinnati (Sections S1 and S3). ICP-MS analyses were conducted at the Center for Applied Isotope Studies at the University of Georgia and are discussed completely in the Supplementary Materials (Sections S1, S2 and S4). Stable carbon isotope analyses were conducted at the Center for Applied Isotope Studies at the Reston Stable Isotope Laboratory, United States Geological Survey and are discussed in the Supplementary Materials (Section S5). Extraction of the Fe and Si-rich microspherules from Hopewell archaeological contexts was accomplished in the Ohio Valley Archaeology Labortatory at the University of Cincinnati and are discussed in the Supplementary Materials (Section S6).

\section{Data availability}

All data generated or analyzed during this study are included in this published article (and its Supplementary Information files).

Received: 30 September 2021; Accepted: 18 January 2022

Published online: 01 February 2022

\section{References}

1. DePalma, R. A. et al. A seismically induced onshore surge deposit at the KPg boundary, North Dakota. Proc. Natl. Acad. Sci. 116, 8190-8199 (2019).

2. Teller, J. et al. A multi-proxy study of changing environmental conditions in a Younger Dryas sequence in southwestern Manitoba, Canada, and evidence for an extraterrestrial event. Quat. Res. 93, 60-87 (2019).

3. Barrientos, G. \& Masse, W. The archaeology of cosmic impact: Lessons from two mid-holocene argentine case studies. J. Archaeol. Method Theory 21, 134-211 (2014).

4. Piccardi, L. \& Masse, W. B. Myth and geology. Geol. Soc. Spec. Publ. 273, 177-202 (2015).

5. Tsu, W. S. The observations of Halley's Comet in Chinese history. Popul. Astron. 42, 191 (1934).

6. Rigby, E., Symonds, M. \& Ward-Thompson, D. A comet impact in AD 536?. Astron. Geophys. 45, 23-26 (2004). 
7. Chodas, P. \& Yeomans, D. The orbital motion and impact circumstances of Comet Shoemaker-Levy 9. Int. Astron. Union Colloq. 156, 1-30 (1996).

8. Kelley, M. C., Seyler, C. E. \& Larsen, M. F. Two-dimensional turbulence, space shuttle plume transport in the thermosphere, and possible relation to the great siberian impact event. Geophys. Res. Lett. 36, 14 (2009).

9. Hildebrand, A. R. Geochemistry and stratigraphy of the Cretaceous/tertiary boundary impact ejecta (University of Arizona, Tucson, 1992).

10. Kalleson, E., Dypvik, H. \& Nilsen, O. Melt-bearing impactites (suevite and impact melt rock) within the Gardnos structure, Norway. Meteorit. Planet. Sci. 45, 798-827 (2010).

11. Folco, L. et al. Impact craters and meteorites: The Egyptian record. In The Geology of Egypt Hamimi Regional Geology Reviews (eds Hamimi, Z. et al.) (Springer, New York, 2020). https://doi.org/10.1007/978-3-030-15265-9_11.

12. Kalinowski, D. D. The meteorites of Ohio (The Ohio State University, Columbus, 1972).

13. Prüfer, O. Prehistoric Hopewell Meteorite collecting: Context and implications. Ohio J. Sci. 61, 341-352 (1961).

14. Prüfer, O. Prehistoric Hopewell Meteorite collecting: Further evidence. Ohio J. Sci. 62, 314-316 (1962).

15. Kimberlin, J. \& Wasson, J. T. Comparison of Iron Meteoritic Material from Ohio and Illinois Hopewellian Burial Mounds. Am. Antiq. 41, 489-493 (1976).

16. Carr, C. \& Sears, D. W. G. Toward an analysis of the exchange of meteoritic iron in the Middle Woodland. Southeast. Archaeol. 4, 79-92 (1985).

17. McCoy, T. J. et al. The Anoka, Minnesota iron meteorite as parent to Hopewell meteoritic metal beads from Havana, Illinois. J. Archaeol. Sci. 81, 13-22 (2017).

18. Mills, L. Mitochondrial DNA analysis of the Ohio Hopewell of the Hopewell Mound Group (The Ohio State University, Columbus, 2003).

19. Tankersley, K. B. Archaeological geology of the turner site complex, Hamilton County, Ohio. N. Am. Archaeol. 28, 271-294 (2007).

20. Connolly, R. P. \& Lepper, B. T. The Fort Ancient Earthworks: Prehistoric Lifeways of the Hopewell Culture in Southwestern Ohio (Ohio Historical Society, Columbus, 2004).

21. Fagan, B. Ancient North America (Thames \& Hudson, London, 2005).

22. Price, T. D. \& Feinman, G. M. Images of the Past (Mayfield Pub Co, Mountain View, 1997).

23. Brose, D. S. \& Greber, N. Hopewell Archaeology: The Chillicothe Conference (Kent State University Press, Kent, 1979).

24. Byers, A. M. \& Wymer, D. A. Hopewell Settlement Patterns, Subsistence, and Symbolic Landscapes (University of Florida, Gainsville, 2010).

25. Greber, N. Chronological Relationships Among Ohio Hopewell Sites: Few Dates and Much Complexity. In Theory, Method, and Practice in Modern Archaeology (eds Jeske, R. J. \& Charles, D. K.) 88-113 (Praeger Publishers, Westport, 2003).

26. Atwater, C. Descriptions of the Antiquities Discovered in the State of Ohio and Other Western States (Transactions and Collections of the American Antiquarian Society, Worcester, 1820).

27. Metz, C. The Prehistoric Monuments of the Little Miami Valley. J. Cincinnati Soc. Nat. Hist. 1, 119-128 (1878).

28. Metz, C. The prehistoric monuments of anderson township, Hamilton County, Ohio. J. Cincinnati Soc. Nat. Hist. 4, 293-305 (1881).

29. Metz, C. A Brief Description of the Turner Group of Prehistoric Earthworks in Anderson Township, Hamilton County, Ohio (Cincinnati Museum, Cincinnati, 1911).

30. Willoughby, C. C. \& Hooten, E. A. Turner Group of Earthworks Hamilton County, Ohio (Peabody Museum of American Archaeology and Ethnology, Harvard University, Cambridge, 1922).

31. Bunch, T. E. et al. Very high-temperature impact melt products as evidence for cosmic airbursts and impacts 12,900 years ago. Proc. Natl. Acad. Sci. 109, 1903-1912 (2012).

32. Anfinogenova, Y. \& Anfinogenov, J. Challenges of identifying putative planetary-origin meteorites of non-igneous material. Geosci. Front. 10, 1879-1890 (2019).

33. Hou, Q. L. et al. Platinum group element abundances in a peat layer associated with the Tunguska event, further evidence for a cosmic origin. Planet. Space Sci. 52, 331-340 (2004).

34. Firestone, R. B. et al. Evidence for an extraterrestrial impact 12,900 years ago that contributed to the megafaunal extinctions and the Younger Dryas cooling. Proc. Natl. Acad. Sci. 104, 16016-16021 (2007).

35. Scott, E. R. D. Pallasites: Olivine-metal textures, metal compositions, minor phases, origins, and insights into processes at coremantle boundaries of asteroids. Lunar Planet. Sci. 48, 1037 (2017).

36. Gertsch, B. et al. The Cretaceous-Tertiary boundary (KTB) transition in NE Brazil. J. Geol. Soc. Lond. 170, 249-262 (2013).

37. Moore, C. R. et al. Widespread platinum anomaly documented at the Younger Dryas onset in North American sedimentary sequences. Nat. Sci. Rep. 7, 44031 (2017).

38. Putnam, F. W. Prehistoric remains in the Ohio Valley. Century Mag. 39, 698-703 (1890).

39. Tankersley, K. B. \& Newman, R. Dr. Charles Louis Metz and the American Indian Archaeology of the Little Miami River Valley (Little Miami Publishing Company, Milford, 2016).

40. Fowke, G. Archaeological History of Ohio (Ohio State Archaeological and Historical Society, Columbus, 1902).

41. Tankersley, K. B. \& Balantyne, M. X-ray Power Diffraction Analysis of Late Holocene Reservoir Sediments. J. Archaeol. Sci. 37, $133-138$ (2010).

42. Kennett, J. P. et al. Widespread Bayesian-modeled ages supports younger dryas impact hypothesis. Proc. Natl. Acad. Sci. 112, 4344-4353 (2015).

43. Hall, R. L. An anthropocentric perspective for eastern United States prehistory. Am. Antiq. 42, 499-518 (1977).

44. Hall, R. L. An Archaeology of the Soul: North American Indian Belief and Ritual (University of Illinois Press, 1997).

45. McCoy, et al. Ašiihkiwi neehi kišsikwi myaamionki: Earth and Sky: The Place of the Myaamiaki (Miami Tribe of Oklahoma, Miami, 2011).

46. Howard, J. H. Shawnee!: The Ceremonialism of a Native Indian Tribe and Its Cultural Background (Ohio University Press, Columbus, 1981).

47. Morgan, L. H. League of the Ho-dé-no-sau-nee or Iroquois (Sage Publishing, Rochester, 1851).

48. Spencer, J. Shawnee Folk-Lore. The Journal of American Folklore 22, 319-326 (1909).

49. Deloria, V. Red Earth, White Lies (Fulcrum Publishing, Golden, 1997).

50. Clube, V. \& Napier, B. The Cosmic Serpent: A Catastrophist View of Earth History (Universe Books, New York, 1982).

\section{Acknowledgements}

Field and laboratory work was undertaken between 2019 and 2021 as part of the University of CincinnatiHopewell Comet Airburst Project co-directed by Kenneth Barnett Tankersley and Stephen Meyers. We are especially grateful to Cory Christopher and the Cincinnati Nature Center, Mayor Mark Kobasuk and the Village of Newtown, the Greenlawn Cemetery of Milford, Steven Wetz and the City of Marietta Ohio, Jessica Spencer, Adam McCosham and the Great Parks of Hamilton County, Paul Gardner and the Archaeological Conservancy, Jon Seymour and Oxbow Inc., Beth McCord and the Indiana State Historic Preservation Office of the Indiana Department of Natural Resources, Berea College, and Ryan Merkle and the Scenic River Canoe Excursions 
of Cincinnati. None of this work would have been possible without the efforts Larry Sandman, Maria Nicole Saniel-Banrey, Harrison Todd Stanley, Benjamin Lewton, Sarah Jordan, Maddie Moeller, and Dale Eads. Field and laboratory work for this study was made possible with funding from the Court Family Foundation and the Charles Phelps Taft Foundation. The editor and anonymous reviewers greatly improved our paper.

\section{Author contributions}

K.B.T. conceived of the project and wrote most of the manuscript. K.B.T. and S.D.M. directed the fieldwork. S.D.M. conducted the soil and stratigraphic analyses. K.B.T., J.A.J., and L.H. directed the laboratory work. D.L.L. and S.A.M. conducted the archaeobotanical analyses.

\section{Competing interests}

The authors declare no competing interests.

\section{Additional information}

Supplementary Information The online version contains supplementary material available at https://doi.org/ 10.1038/s41598-022-05758-y.

Correspondence and requests for materials should be addressed to K.B.T.

Reprints and permissions information is available at www.nature.com/reprints.

Publisher's note Springer Nature remains neutral with regard to jurisdictional claims in published maps and institutional affiliations.

(c) (i) Open Access This article is licensed under a Creative Commons Attribution 4.0 International License, which permits use, sharing, adaptation, distribution and reproduction in any medium or format, as long as you give appropriate credit to the original author(s) and the source, provide a link to the Creative Commons licence, and indicate if changes were made. The images or other third party material in this article are included in the article's Creative Commons licence, unless indicated otherwise in a credit line to the material. If material is not included in the article's Creative Commons licence and your intended use is not permitted by statutory regulation or exceeds the permitted use, you will need to obtain permission directly from the copyright holder. To view a copy of this licence, visit http://creativecommons.org/licenses/by/4.0/.

(C) The Author(s) 2022 